\title{
Gene Flow in Phaseolus Beans and Its Role as a Plausible Driver of Ecological Fitness and Expansion of Cultigens
}

\author{
María Isabel Chacón-Sánchez ${ }^{1 *}$, Jaime Martínez-Castillo², Jorge Duitama ${ }^{3}$ and \\ Daniel G. Debouck ${ }^{4}$ \\ 1 Departamento de Agronomía, Facultad de Ciencias Agrarias, Universidad Nacional de Colombia, Bogotá, Colombia, \\ 2 Unidad de Recursos Naturales, Centro de Investigación Científica de Yucatán, Yucatán, Mexico, ${ }^{3}$ Systems and Computing \\ Engineering Department, Universidad de los Andes, Bogotá, Colombia, ${ }^{4}$ Genetic Resources Program, International Center \\ for Tropical Agriculture - CIAT, Cali, Colombia
}

\section{OPEN ACCESS}

Edited by:

Giancarlo Conde Xavier Oliveira, University of São Paulo, Brazil

Reviewed by: Elizabeth Ann Veasey, University of São Paulo, Brazil Marcelo Cavallari, Brazilian Agricultural Research Corporation (EMBRAPA), Brazil Marilia Burle,

Embrapa Genetic Resources and Biotechnology, Brazil

*Correspondence:

María Isabel Chacón-Sánchez michacons@unal.edu.co

Specialty section:

This article was submitted to Evolutionary and Population Genetics, a section of the journal

Frontiers in Ecology and Evolution

Received: 18 October 2020 Accepted: 28 April 2021

Published: 21 May 2021

Citation:

Chacón-Sánchez MI,

Martínez-Castillo J, Duitama J and

Debouck DG (2021) Gene Flow in Phaseolus Beans and Its Role as a Plausible Driver of Ecological Fitness

and Expansion of Cultigens.

Front. Ecol. Evol. 9:618709. doi: 10.3389/fevo.2021.618709
The genus Phaseolus, native to the Americas, is composed of more than eighty wild species, five of which were domesticated in pre-Columbian times. Since the beginning of domestication events in this genus, ample opportunities for gene flow with wild relatives have existed. The present work reviews the extent of gene flow in the genus Phaseolus in primary and secondary areas of domestication with the aim of illustrating how this evolutionary force may have conditioned ecological fitness and the widespread adoption of cultigens. We focus on the biological bases of gene flow in the genus Phaseolus from a spatial and time perspective, the dynamics of wild-weedy-crop complexes in the common bean and the Lima bean, the two most important domesticated species of the genus, and the usefulness of genomic tools to detect inter and intraspecific introgression events. In this review we discuss the reproductive strategies of several Phaseolus species, the factors that may favor outcrossing rates and evidence suggesting that interspecific gene flow may increase ecological fitness of wild populations. We also show that wild-weedy-crop complexes generate genetic diversity over which farmers are able to select and expand their cultigens outside primary areas of domestication. Ultimately, we argue that more studies are needed on the reproductive biology of the genus Phaseolus since for most species breeding systems are largely unknown. We also argue that there is an urgent need to preserve wild-weedy-crop complexes and characterize the genetic diversity generated by them, in particular the genome-wide effects of introgressions and their value for breeding programs. Recent technological advances in genomics, coupled with agronomic characterizations, may make a large contribution.

Keywords: wild-weedy-crop complexes, introgression genomic footprint, crop diffusion, center of diversity, breeding system, pollinator behavior, common bean, Lima bean

\section{INTRODUCTION}

The genus Phaseolus is native to the Americas with wild species growing from Connecticut in the United States [for P. polystachyus (L.) B.S. \& P.: Dohle et al. (2019)] down to the province of Córdoba in Argentina [for wild P. vulgaris L.: Drewes (2008)]. From about eighty species currently known in Phaseolus (Ulloa Ulloa et al., 2018), five species were affected by domestication, namely 
$P$. acutifolius A. Gray (the tepary bean), P. coccineus L. (the scarlet runner), $P$. dumosus Macfady (the year-bean), $P$. lunatus L. (the Lima bean) and P. vulgaris L. (the common bean). Two independent domestications occurred for both the Lima bean (Motta-Aldana et al., 2010) and the common bean (Chacón et al., 2005; Bitocchi et al., 2013) in Mesoamerica and the Andes of South America, while a single domestication occurred for the tepary (Muñoz et al., 2006), the scarlet runner (GuerraGarcía et al., 2017) and the year-bean (Schmit and Debouck, 1991), all of them in Mesoamerica. Current research dates the initial domestication events at approximately 8,000 years before present (Mamidi et al., 2011). After domestication, landraces were diffused outside their areas of origin to different places in the Americas, and after 1493, P. vulgaris, P. lunatus and to a lesser degree $P$. coccineus were introduced in different parts of the Old World, as cultivated varieties for their edible seeds (Kaplan and Kaplan, 1992). In the case of the former two, materials of the Mesoamerican and Andean gene pools were brought into new lands, and sometimes were grown together.

Due to the widespread distribution of wild Phaseolus species in the Americas, the multiple cases of domestication and the worldwide diffusion of cultivated forms, the genus Phaseolus offers a great opportunity to examine the role and extent of gene flow in primary and secondary centers of diversity and its evolutionary consequences. Since the beginning of domestication in the genus Phaseolus, ample opportunities for gene flow between crop and wild relatives have existed through wildweedy-crop complexes. In spite of the profuse nature of these complexes, very little is known about the genetic variability that is being generated and its adaptive significance. With this review we intend to illustrate how gene flow may have conditioned ecological fitness and the widespread adoption of cultigens. Given the high risk that faces the continuity of these complexes, due to diverse factors such as low habitat conservation and changes in farmers' behavior, there is an urgent need to preserve these complexes and to understand their role in generating useful recombinants for breeding programs that may help overcome current and future challenges.

This review is organized into six sections. In the first section, the biological bases of gene flow in the genus Phaseolus are established, namely floral morphology, behavior of pollinators and breeding systems in a comparative framework. The second section addresses the spatial context of gene flow, particularly the widespread occurrence of gene flow among wild and domesticated populations, the origin of weedy forms, the large variation in outcrossing rates among different localities, the direction of gene flow and their implications for adaptation of wild populations and cultigens to new and changing environments. In the third section, a time perspective for gene flow is introduced, namely, the importance of gene flow between landraces and their wild relatives in primary areas of origin and the role of gene flow in secondary centers of diversity where cultivated forms were later introduced and their implications for breeding programs. The fourth and fifth sections review in more detail the dynamics of wild-weedy-crop gene flow in the two most studied Phaseolus species, the common bean and the Lima bean. For the common bean, the current knowledge of wild-weedy-crop gene flow along its natural range of distribution is discussed. For the Lima bean, the Yucatán Peninsula represents a natural laboratory to study wild-weedy-crop gene flow in this species. This is the region that houses the largest number of native varieties of this crop in all of Mexico, which grow sympatrically with wild populations. This contact has led to the formation of wild-weedy-crop inter-reproductive complexes, whose existence is favored both by intrinsic characteristics of the species and by characteristics of the traditional Mayan agriculture. In this section, the research carried out in Mexico on this important micro-evolutionary process is reviewed along with its implications on the diversity and genetic structure of Lima bean in the Yucatán Peninsula. The last section is devoted to review how the genomic footprints of introgression in wild and domesticated populations are detected. The results of recent studies in Phaseolus species where different genomic tools have been used are presented, with a focus on the use of these tools to detect introgression events between species and between gene pools within species. The identification of these events will open hypotheses of spontaneous gene flow or early breeding efforts and can facilitate the identification of genetic drivers for different traits.

\section{SECTION 1: BIOLOGICAL BASES OF GENE FLOW IN THE GENUS Phaseolus}

The legumes of the subtribe Phaseolinae (Leguminosae: Phaseoleae), which includes Phaseolus (Lackey, 1983; Schrire, 2005), have papilionaceous zygomorphic flowers with five petals: the standard, two wings, and two petals almost united forming the keel [see Doutt (1932); Figures 1-3], and the fruit from a single carpel is defined as a pod (with two valves united along two sutures, the seeds adhering to the placenta through the funiculi along the dorsal suture) (Berrie, 1977). Because of the vascular tissues in the ovary, the funiculi alternate in joining to the placenta (Doutt, 1932). In the wild, the pod opens along the sutures, and because of the fibers present in the valves there is a strong twisting of such valves, resulting in the spreading of the seeds a couple of meters from the mother plant [maximum $5.5 \mathrm{~m}$ in wild Lima bean: Baudoin et al. (2004)]. For significant gene flow - the purpose of this review, this short distance would stress the importance of pollen carried by pollinators. The functional pollination unit is the papilionaceous flower itself (Figure 1A); in terms of functionality equally important may be the biochemistry of nectar (Baker and Baker, 1983), scents or attractants that will not be considered in this work. This flower consists of the standard acting as attraction and guiding device, the wings and the keel as landing platform for pollinators, and the keel as guide to the nectar source and the protecting unit for the stamens and style (Arroyo, 1981; Sousa-Peña et al., 1996).

The many ways the papilionaceous corolla is spatially organized to attract specific pollinators among the hundreds possible in the Neotropics (Opler, 1983) have confused bean taxonomists for almost two centuries. On dried specimens it is often difficult to assess the relative length of the standard vs. that of the wings, the position of the wings, the symmetry of the 

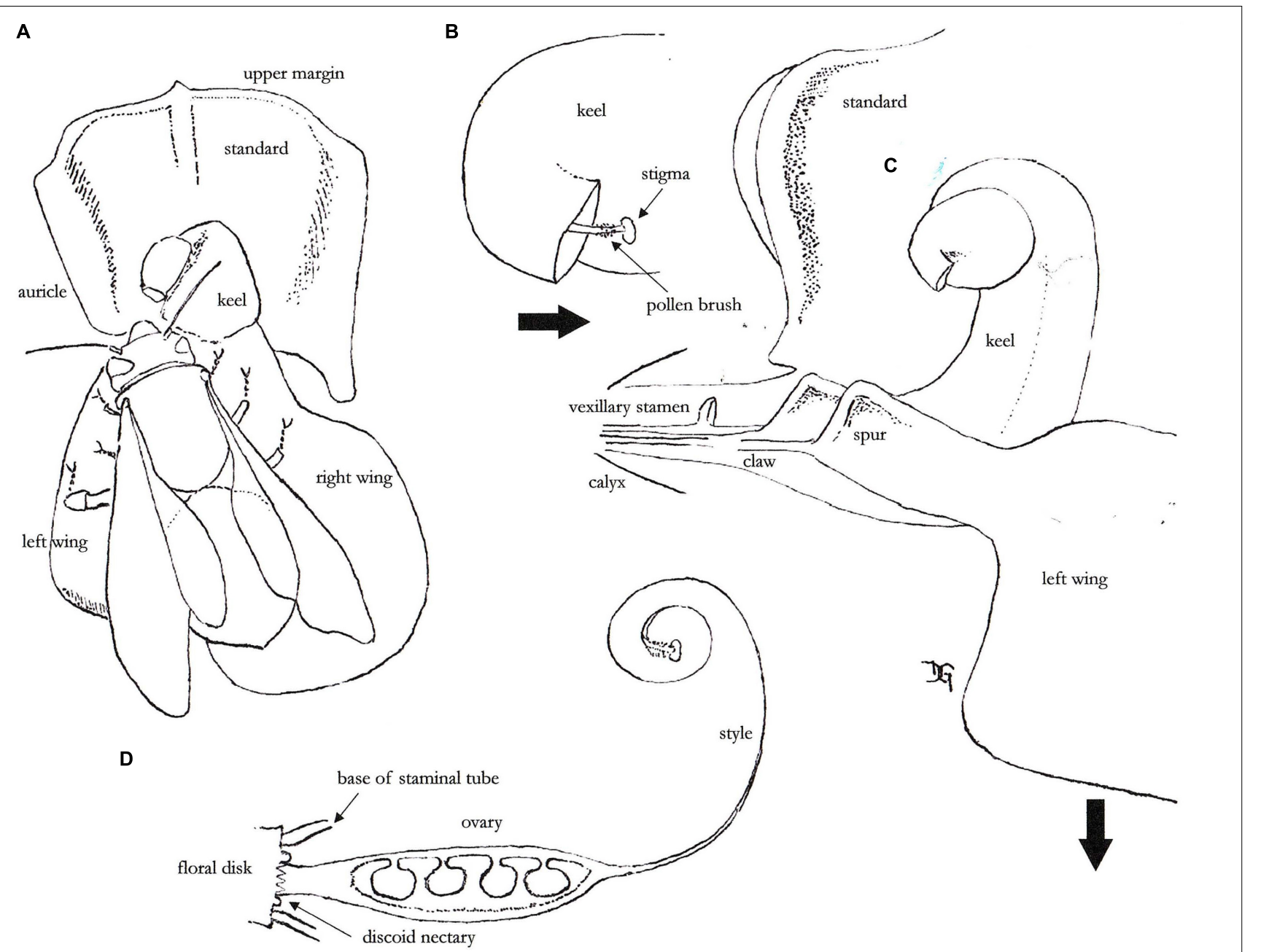

FIGURE 1 | The different parts of the flower in P. dumosus. (A) A bee has landed and located itself on the left wing. (B) Protrusion of the style end outside the cavity of the keel (direction indicated by the arrow). (C) The spur of the left wing has been slightly displaced to the right to show how it fits onto the lower part of the left petal of the keel (the arrow indicates the downward pressure exerted by the pollinator). (D) The denticulate discoid nectary between the base of the ovary and the staminal tube.

corolla or the final twisting of the keel. For example, the flowers of Figure 2 belong today to species of six different legume genera, although they were all once considered as species of Phaseolus as indicated by the basionyms (Delgado-Salinas et al., 2011). Macroptilium species usually have spreading prominent wings (Figure 2b), brightly colored in contrast to an often greenish or less colored standard. The distal tightly coiled part of the keel in Leptospron (Figure 2a) reminds some Phaseolus species (e.g., P. albiflorus Freytag \& Debouck, Figure 3a). Ancistrotropis species have a narrow hooked distal part of the keel (Figure 2c), in contrast with the 2.5 loosely coiled forward spreading keel of Helicotropis (Figure 2f), yet different from Sigmoidotropis speciosa (Figure 2d) or Cochliasanthus caracalla (Figure 2e). But in Phaseolus species (Figures 3a-i) the spatial configuration of the corolla follows the same general pattern. This can be explained by common descent (Darwin, 1859). Further, DelgadoSalinas et al. (1993) have shown the genus to be monophyletic. We shall now briefly describe this pattern.
The five petals are inserted on the floral disk that has an active discoid nectary (Figures 1A,D). Mature pollen grains are shed with anthers opening and can fall on the stigmatic surface at the end of the style. Since pollen fall and stigma receptivity are synchronous and occurring at colored floral bud stage, self-pollination is most common in P. vulgaris (Webster et al., 1977), but there might be a little distance between the pack of anthers and the stigma as often observed in $P$. coccineus (Webster et al., 1980). This together with maturity differences (Bliss, 1980) may favor allogamy. No genetic incompatibility has been reported within Phaseolus species (Evans, 1976), although post-fertilization hybrid weakness may exist caused by genetic distance between gene pools within long-range species (Koinange and Gepts, 1992). Cytoplasmic male-sterility (CMS) inducing failure of the microgametogenesis has however been observed in wild populations of $P$. coccineus, $P$. dumosus and $P$. vulgaris, as a mechanism to promote intra-specific gene flow (Hervieu et al., 1993; Hervieu et al., 1994). About self-(in)compatibility, 


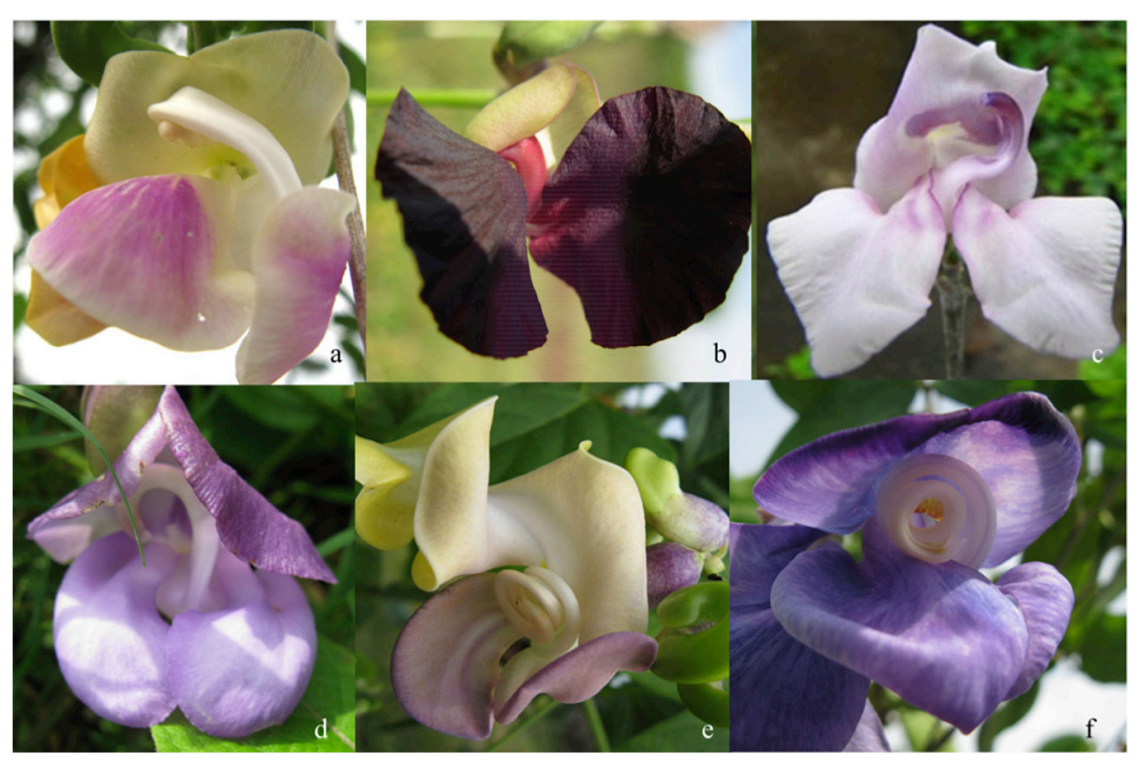

FIGURE 2 | (a) Leptospron adenanthum (G. Meyer) A. Delgado. (b) Macroptilium atropurpureum (DC.) Urban. (c) Ancistrotropis peduncularis (Fawcett \& Rendle) A. Delgado. (d) Sigmoidotropis speciosa (Kunth) A. Delgado. (e) Cochliasanthus caracalla (L.) Trew. (f) Helicotropis linearis (Kunth) A. Delgado (photographs taken by D.G. Debouck except e by A. Ciprián).

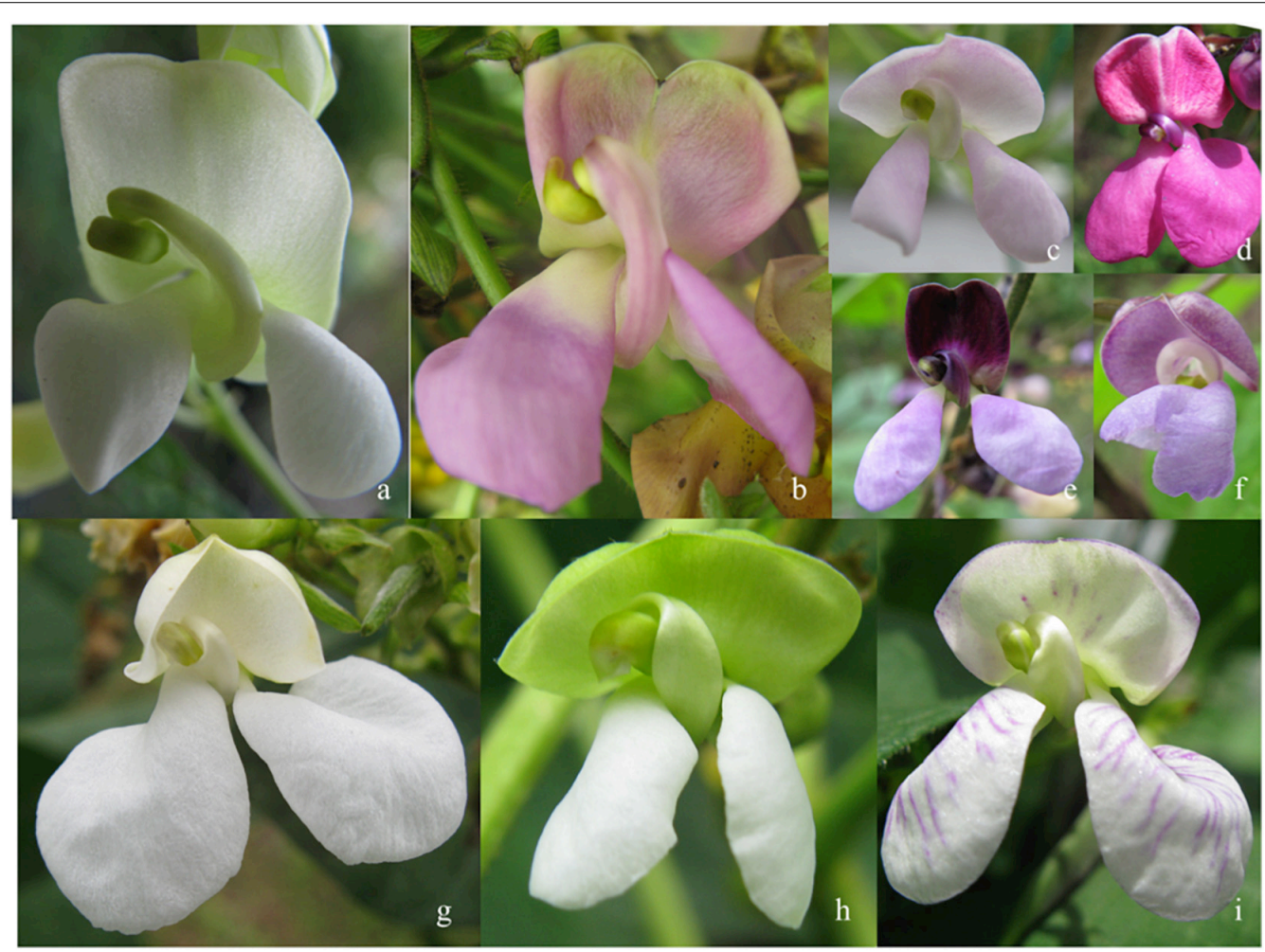

FIGURE 3 | (a) Phaseolus albiflorus. (b) P. chiapasanus. (c) P. acutifolius. (d) P. talamancensis. (e) P. augusti. (f) P. xanthotrichus. (g) P. dumosus. (h) P. lunatus. (i) P. vulgaris (photographs taken by D.G. Debouck).

Arroyo (1981) reported five species tested [out of the 82-85 species existing in the genus Phaseolus: Ulloa Ulloa et al. (2018)] actually the five cultivated species, and one auto-incompatible:
P. coccineus. This author, however, indicates this last record as dubious: if pollen of the same flower is brought on the stigma, the species is self-fertile (Ibrahim and Coyne, 1975). 


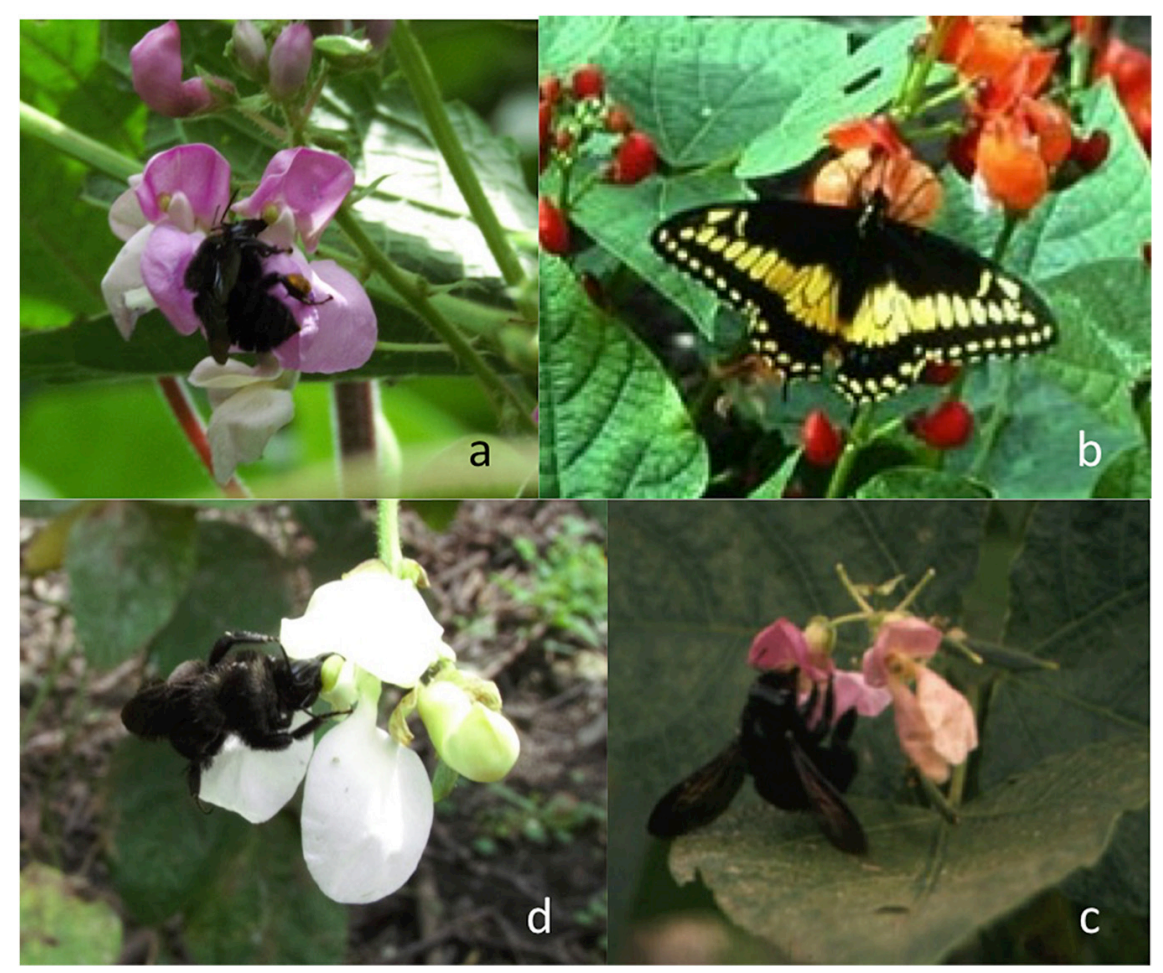

FIGURE 4 | Wild insects pollinating flowers of (clockwise from upper left): (a) dumosus; (b) coccineus, and (c,d) vulgaris. Note that in (a) and (d) the wild bumblebees have a weight problem to push the left wing downward (the bumblebee in (d) performing better and being rewarded by the stigma on its face), while in contrast in (c) the heavy carpenter bee needs the two wings to keep its balance. In (b) a swallowtail Papilio just uses the two wings as support while sucking the nectar (photo credit: (a) and (d) J. Gereda, Tenerife, Valle del Cauca, Colombia, 2020; (b) D.G. Debouck, Popayán, Cauca, Colombia, 1978; (c) same, 1988).

Delgado-Salinas (1985) does not report self-incompatibility in the genus, but the need in many species for the stigma cuticle to be broken. This might be the ultimate explanation why tripping by bumblebees (Figures 4a,d) has a positive effect on seed yield in P. vulgaris (Ibarra-Pérez et al., 1999), and this action by visiting pollinators shall now be explained.

There is a very close contact between the left wing (for the observer) and the left petal (same) of the keel; further there is a little pouch in the keel close to the basal disk that makes these two petals to adhere strongly at this point (Delgado-Salinas, 1985; Figure 1C). A pressure on the left wing pushes the keel downward (Figures 1C, 4d), thus exposing the stigma and the pollen brush to the visiting bee (Figure 1B). This move of the staminal column and style is defined technically as tripping (Ibarra-Pérez et al., 1999). Through its weight the visiting bee or bumble bee can collect pollen from the pollen brush (Lavin and Delgado-Salinas, 1990) on the forefront of its head, while it has opened the access to the nectar. The nectar accumulates in the narrow space between the wings and keel claws, and the base of the staminal tube and ovary (Figure 1D). A similar pollination mechanism has been reported by Hedström and Thulin (1986) for Vigna vexillata (L.) A. Rich (a legume of the same subtribe) in the field in Costa Rica. As reported by Sousa-Peña et al. (1996), there are differences in ultra-violet light absorption between the keel, the wings and the upper margin of standard, almost guiding the pollinator toward the base of the left wing. This different absorption is due to subtle differences in the epidermis and cuticle of the petals. When visiting the next flower, with pollen from the previously visited flower on its forefront, the bee can deposit alien pollen on the newly exposed stigma, and wide cross can occur if the stigma is receptive before auto-pollination. Fertilization normally occurs $8 \mathrm{~h}$ after anthesis (Weinstein, 1926), thus that lag gives some chance to alien pollen brought by an early visiting insect. In pods where hybridization happened, multiple paternity may occur with a frequency of 5-8\%, with the hybrid seeds frequently located in the stylar part of the pod (Ibarra-Pérez et al., 1996). The visiting bee is rewarded principally by nectar (Webster et al., 1982), pollen and possibly other nutrients (lipids, amino acids) of the stigmatic exudate (Lord and Webster, 1979). On bee leaving, the stamens and the end of style with stigma and pollen brush return into the keel cavity (Figure 1B), making possible the visit by another bee (Berrie, 1977). Further, the little changed aspect of the flower (see Figures $\mathbf{5 c}, \mathbf{d}$ ) opens up the possibility of multiple paternity (Ibarra-Pérez et al., 1996). Before probing, a second bee possibly does not know what amount of nectar is left. Tripping boosts seed yield in common bean (Darwin, 1858; Ibarra-Pérez et al., 1999) and definitely in scarlet runner (Free, 1966; Kendall and Smith, 1976). So, the floral morphology, color and spatial orientation of the corolla (from the insect perspective), abundance, timing and chemical composition of the nectar have all resulted from co-evolution between these legume plants and their pollinators over millions of years [the age of 


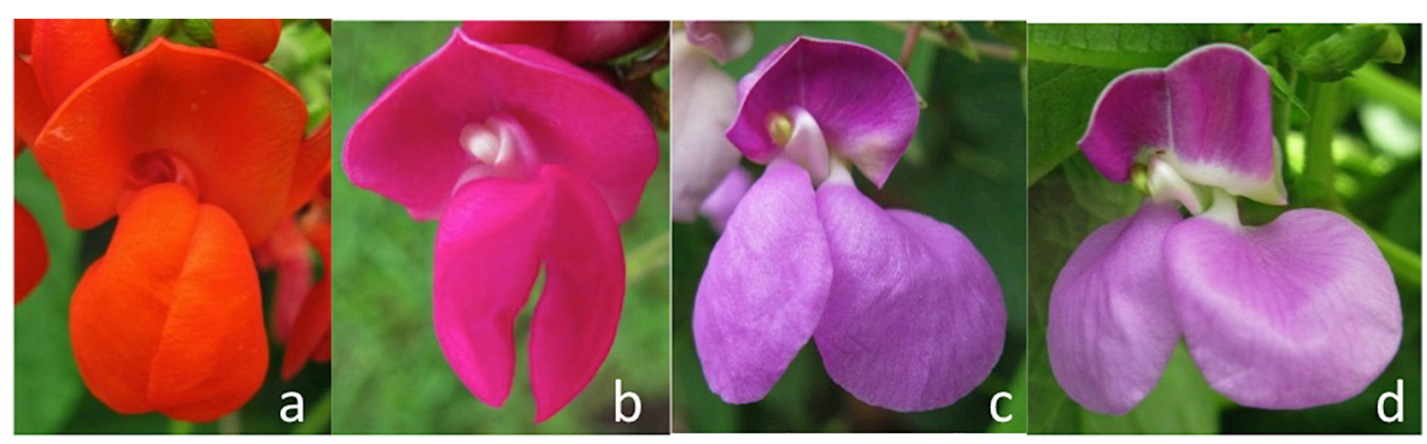

FIGURE 5 | Flowers of species of section Phaseoli DC often pollinated by hummingbirds: (a) P. coccineus, (b) P. costaricensis, (c) P. dumosus, and (d) P. vulgaris; note that in (c) in contrast to (d) the flower has not been visited yet (photographs taken by D.G. Debouck).

Phaseolus has been estimated at 8 million years: Delgado-Salinas et al. (2006) or at 15 million years: Garcia et al. (2021)].

Phaseolus species (Figures 3a-i) display all a close counterclockwise 1.5-2-3-coiled keel and spreading to the left (for the observer), resulting thus in asymmetrical flowers. In section Xanthotricha A. Delgado the coiling ends up tightly but toward the inner part of the corolla (Figure 3f; Freytag and Debouck, 2002). The largest flowers are the ones of P. chiapasanus Piper (42 mm long x $25 \mathrm{~mm}$ high) (Figure 3b), while the smallest ones are the ones of $P$. macvaughii A. Delgado $(6 \times 4 \mathrm{~mm})$. The wide spreading of the wings is common in the Phaseoli DC. section (see P. dumosus, Figures 3g, 5c, and $P$. vulgaris, Figures $\mathbf{3 i}, \mathbf{5 d}$ ). The standard can be variously reflected, poorly in $P$. zimapanensis A. Delgado to strongly in P. reticulatus Freytag \& Debouck (Freytag and Debouck, 2002) and can be asymmetrical. Auricles can be strongly developed as in P. pluriflorus Maréchal, Mascherpa, \& Stainier or not at all as in $P$. parvulus Greene, in the same section! In the wild, flower colors display a huge variation, mostly in tones of lilac and purple, but not in yellow or blue. Some herbarium labels may report yellow, but this refers to (mostly white) flowers 1 day after anthesis (flower opening). Scarlet or brick red exists in $P$. coccineus (Figure 5a), dark orange in P. glabellus Piper, old rose in P. albescens McVaugh ex R. Ramírez \& A. Delgado, magenta in $P$. costaricensis Freytag \& Debouck (Figure 5b) and $P$. lignosus Britton. Pure white flowers are not so frequent in wild species; they are found in $P$. albiflorus and feral $P$. dumosus (Figure 3g), in contrast with cultivated varieties, where they are often associated with white or cream seeds. A frequent color pattern is that of deep purple or lilac standard with lighter wings (illustrated here in $P$. augusti Harms, Figure 3e). The petals might be equally colored as in P. talamancensis Debouck \& Torres (Figure 3d). Greenish standards are found in P. lunatus (Figure $3 \mathbf{h}$ ) and $P$. oligospermus Piper, while distinctly veined standards are found in $P$. jaliscanus Piper, P. marechalii A. Delgado and P. nodosus Freytag \& Debouck.

Effective pollinators (Figures $4 \mathbf{a}-\mathbf{d}$ ) reported so far include medium to large size species of Hymenoptera of the following genera: Apis (Darwin, 1858; Free, 1966; Free and Racey, 1968; Kendall and Smith, 1976; Ibarra-Pérez et al., 2000; Regina-Royer et al., 2000), Bombus (Henslow, 1878; Barrons,
1938; Free and Racey, 1968; Kendall and Smith, 1976; Okonkwo and Clayberg, 1984; Ibarra-Pérez et al., 2000; Silveira et al., 2001; Figure 4a), Megachile and Xylocopa (Bliss, 1980; Stoetzer, 1984; Hardy et al., 1997; Ramírez-Delgadillo and Delgado-Salinas, 1999; Regina-Royer et al., 2000; Figure 4c). Thrips Frankliniella seem also involved in cross pollination of common bean (Mackie and Smith, 1935; Proctor et al., 1996) and Lima bean (Allard and Workman, 1963). Hummingbirds have been reported visiting flowers of $P$. coccineus (Burquez and Sarukhán, 1980; Sousa-Peña et al., 1996), P. costaricensis (Freytag and Debouck, 1996), and P. vulgaris (Mazariegos, 2000).

It is noteworthy that the species of the genus with the most noticeable blossoms composed by multiflowered racemes of scarlet and carmine flowers (Figures 5a-d) are pollinated by hummingbirds; according to Proctor et al. (1996) insects do not perceive that color, leaving thus the prime nectar to these high-energy demanding birds. Nectar robbers such as some bumblebees making a hole at the base of the corolla have been reported (Henslow, 1878; Free, 1968; Inouye, 1983) and affect yield (Kendall and Smith, 1976). Butterflies also are visiting insects (Figure 4b), whose very long proboscis may compensate for the lack of pressure applied on the left wing. Although pollinators seem active throughout the day, it seems that effective pollination occurs during the 1-4 h after dawn under increasing temperature (Free, 1968; Burquez and Sarukhán, 1980; Hardy et al., 1997).

The floral morphology described above and the presence of accessible nectar at the internal base of the flower is conducive to autogamy but with various degrees of outcrossing (IbarraPérez et al., 2000). Common bean and Lima bean have been usually reported as autogamous crops [Webster et al. (1977, 1979) respectively], while the scarlet runner has been reported as allogamous (Webster et al., 1980). The wild forms of the former two have limited gene flow [Zoro Bi et al. (2003); RendónAnaya et al. (2017), respectively]. As additional mechanisms that promote outcrossing, one should mention that a couple of common bean plants with cytoplasmic male sterility in fertile accessions are known (Mackenzie, 1991), as well as male sterile plants due to recessive genes (van Rheenen et al., 1979; Mutschler and Bliss, 1980). Tepary bean is cleistogamous (Waines and Barnhart, 2001), and possibly the other species with very small 
flowers [e.g., P. macvaughii, P. microcarpus Mart.]. The breeding systems of the over eighty Phaseolus species are still largely unknown, from cleistogamous to almost fully allogamous, but apparently genetically self-compatible in most cases. Perhaps with few exceptions a mechanism calling for the cooperation of superior insects has been selected to cross plants within populations (or closely neighbor populations) to generate genetic variation and to allow drift and differentiation [as evidenced by molecular marker studies: González Torres et al. (2004); Martínez-Castillo et al. (2006)]. Not less interesting for humans as possible domesticators is selfing in order to keep useful variants; for the beans this additional strategy calls for the cooperation of equally organized organisms to conserve countless variants in order to expand.

\section{SECTION 2: SPATIAL CONTEXT OF GENE FLOW IN THE GENUS Phaseolus}

Producing pure seed of elite bred varieties has been a concern of bean breeders since the beginning of the breeding business. The rate of outcrossing has thus caught breeders' attention in many places. Rates of outcrossing display a huge variation across locations (Table 1). At the same place, the variation can be significant from one year to another, possibly linked to pollinator activity, itself linked to weather conditions (Ibarra-Pérez et al., 1997, 1999). At Davis, California, Allard and Workman (1963) noted a variation of $0.8-9 \%$ over seasons in Lima bean because of thrips activity.

Although more data need to be assembled, it seems that outcrossing rates are higher when wild forms are involved (Gepts et al., 2000). Figure 6 may provide an explanation for such higher rates. As a member of the section Phaseoli including P. coccineus (Porch et al., 2013), the common bean has a stigmatic surface covering the tip of the style and extending internally, and more so in the cultivated form. The bigger size of the terminal part of the style, as illustrated in Figure 6, is probably not caused

TABLE 1 | Outcrossing rates reported for common bean across different places.

\begin{tabular}{lcl}
\hline Country, province, place & $\%$ & Source \\
\hline Brazil, Paraná, Maringá & $0.004-2.25$ & Regina-Royer et al. (2000) \\
Colombia, Valle, Cerrito & $1.5-8.7^{*}$ & Triana et al. (1993) \\
Costa Rica, Alajuela, San José & $0.0-0.096$ & Chaves-Barrantes et al. (2014) \\
Costa Rica, Cartago, Quircot & $0.0-0.199 *$ & Chaves-Barrantes et al. (2009) \\
Ethiopia, Sidamo, Awasa & 4.8 & Stoetzer (1984) \\
Mexico, México, Chapingo & $1.3-7.4$ & Miranda-Colín (1971) \\
Mexico, Puebla, Tecamachalco & 4.5 & Crispín (1960) \\
Mexico, Puebla, northern highlands & $20-55^{\star}$ & Gepts et al. (2000) \\
Puerto Rico, Mayagüez & $0.5-39.3$ & Brunner and Beaver (1989) \\
Spain, Asturias, Villaviciosa & 0.74 & Ferreira et al. (2000) \\
United States, CA, Berkeley & 0.73 & Mackie and Smith (1935) \\
United States, CA, Irvine & $1.6-7.2$ & Ibarra-Pérez et al. (1997) \\
United States, CA, Irvine & $11.5-66.8$ & Wells et al. (1988) \\
United States, CA, Riverside & $1.2-14.5$ & Ibarra-Pérez et al. (1997) \\
\hline
\end{tabular}

*involving wild forms. by chance but related to the bigger size of the flower in many varieties of cultivated common bean, as an indirect consequence of domestication and selection for bigger seeds and fruits (Evans, 1980; Gepts and Debouck, 1991). It is true that flowers [namely of $P$. coccineus of both wild and cultivated forms: Delgado Salinas (1988); Mapes and Basurto (2016)] are consumed by some indigenous peoples of Mexico, but conscious selective pressures for increased flower size have not yet been documented.

Weedy forms being the result of natural crossing between the wild form and its respective derived cultivated form (Beebe et al., 1997; Papa and Gepts, 2003) have been reported in many places in the Americas (Table 2). Apparently, all cultivated bean species continue to freely exchange pollen with their respective wild ancestor; both are interfertile and can be considered as the primary gene pool (Debouck and Smartt, 1995). Even in tepary reported as cleistogamous (Waines and Barnhart, 2001) one weedy form from introgression has been found (accession G40177 from Arizona, in CIAT genebank). One can see that where the bean crop and the respective wild form are sympatric hybridization is occurring: the year-bean $P$. dumosus, although as a crop extant from Veracruz down to Cajamarca, only has hybrid swarms in southwest Guatemala where its true wild form is distributed (Freytag and Debouck, 2002). The wild forms of P. lunatus have a huge distribution, from Sonora and Tamaulipas in Mexico down to the Chaco area (Debouck, 2019). The Lima bean, as a crop, nowadays has a spotty distribution in tropical America, perhaps with the exception of the Peninsula of Yucatan and the Andes of Ecuador and NW Peru, where large planting still occurs and hybrid swarms are frequent (Debouck et al., 1987; Martínez-Castillo et al., 2006). The wild form of the scarlet runner is distributed from Chihuahua down to Jalapa in Guatemala and Francisco Morazán in Honduras (Freytag and Debouck, 2002), and crosses with the landraces are frequent where they are in contact, namely in the Mexican states of Puebla, Oaxaca and Chiapas (Delgado Salinas, 1988). Table 2 shows a few cases representative of the situation.

In common bean crosses occur in both directions (Beebe et al., 1997), but in some places predominantly from the cultivated form into the wild form (Papa and Gepts, 2003; Payró de la Cruz et al., 2005). A similar dominant direction has also been observed in Lima bean (Martínez-Castillo et al., 2007). In both cases, the explanation might be demographic: the cultivated field might offer to pollinators a much bigger mass of pollen (and nectar opportunities) as compared to the small wild population on field borders. Not surprisingly, there might be concern for the accidental introduction of transgene into the wild form (Gepts and Papa, 2003; Haygood et al., 2003; Andersson and de Vicente, 2010). Note some weedy forms may result from regressive mutations toward the wild, namely affecting pod dehiscence, seed weight and speckled color in seed. Such weedy forms can be observed in Lima bean in tropical Africa (e.g., G25246B from Ghana, or G26261B from Nigeria, in CIAT genebank).

Gene flow toward the crop is likely to bring back "wild" traits of dominant nature such as strong pod dehiscence, black speckled seeds, and antinutritional factors (Gepts and Debouck, 1991). These genotypes in the F1 offspring are thus likely to be rogued out by farmers, namely if there is a Sunday 


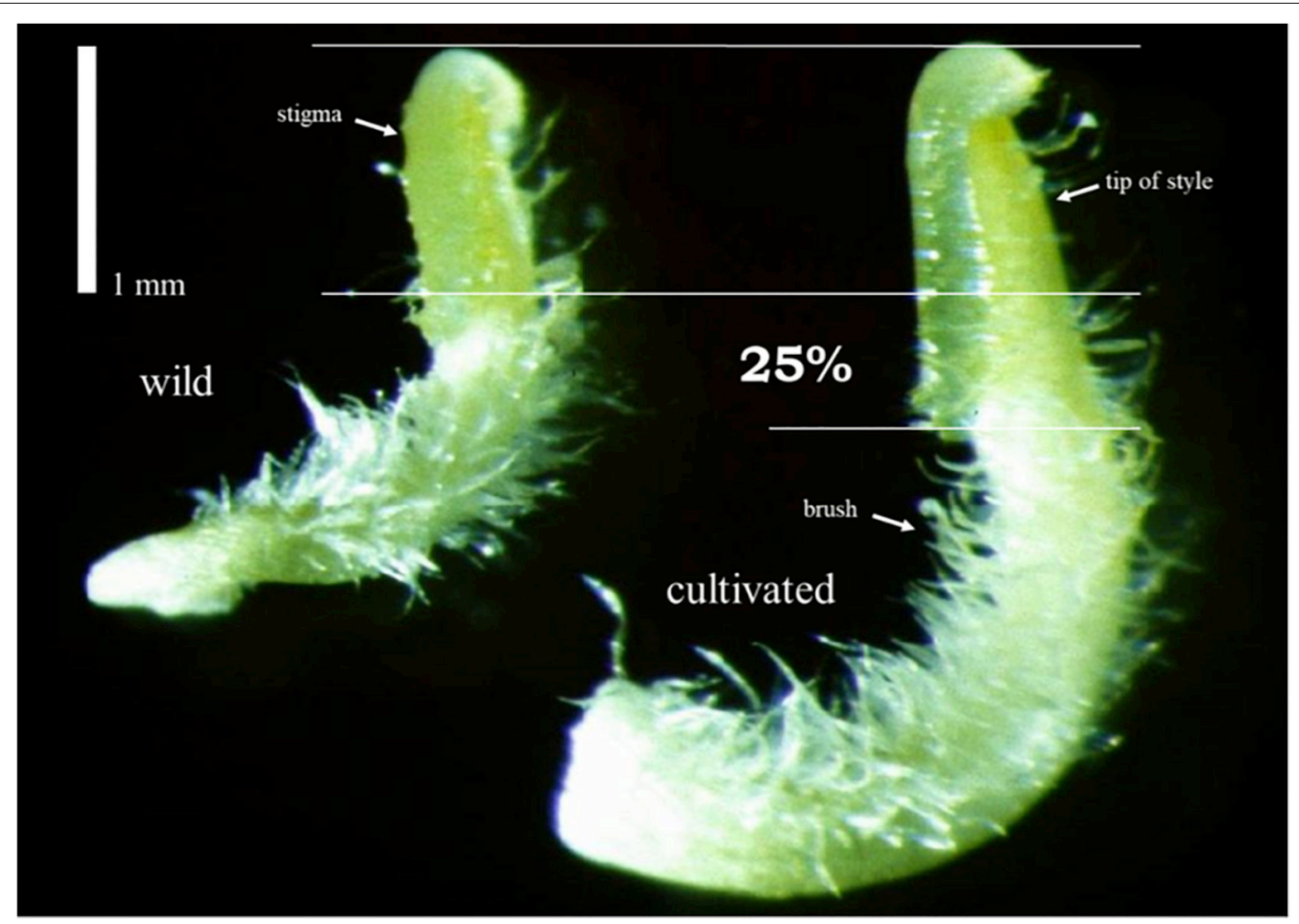

FIGURE 6 | Comparison of tips of styles and stigmas in wild (left) and cultivated (right) $P$. vulgaris. The stigma area is bigger in the cultivated form and expands toward the internal part of the keel (to the left in both cases) (photograph by D.G. Debouck).

market with premium price for uniform seed with light colors [as observed in Michoacán: Zizumbo-Villarreal et al. (2005)]. But that elimination might be reconsidered if there is a food shortage [wild beans have an 8,000 years history as famine-food:

TABLE 2 | Places where weedy forms likely resulting from gene flow have been reported in the Americas.

\begin{tabular}{|c|c|c|}
\hline Bean species & $\begin{array}{l}\text { Country, state/ } \\
\text { province/department }\end{array}$ & Source \\
\hline \multirow[t]{2}{*}{ P. coccineus } & Honduras, Francisco Morazán & Spataro et al. (2011) \\
\hline & Mexico, Morelos & Escalante et al. (1994) \\
\hline P. dumosus & Guatemala, Guatemala & Schmit and Debouck (1991) \\
\hline \multirow[t]{3}{*}{ P. lunatus } & Cuba & Esquivel et al. (1990) \\
\hline & Mexico, Peninsula of Yucatan & Martínez-Castillo et al. (2007) \\
\hline & Peru, Cajamarca & Debouck et al. (1987) \\
\hline \multirow[t]{11}{*}{ P. vulgaris } & Argentina, Salta & Hoc et al. (2006) \\
\hline & Bolivia, Tarija & Freyre et al. (1996) \\
\hline & Colombia, Cundinamarca & Beebe et al. (1997) \\
\hline & Costa Rica, Cartago & Araya Villalobos et al. (2001) \\
\hline & Ecuador, Azuay & Debouck et al. (1993) \\
\hline & Guatemala, Quetzaltenango & Chacón et al. (2005) \\
\hline & Mexico, Chiapas & Papa et al. (2005) \\
\hline & Mexico, Michoacán & Zizumbo-Villarreal et al. (2005) \\
\hline & Mexico, Oaxaca & Gentry (1969) \\
\hline & Mexico, Puebla & González et al. (2005) \\
\hline & Peru, Apurimac & Beebe et al. (1997) \\
\hline
\end{tabular}

Brücher (1954); Debouck (1990)] or if the beans are cooked by toasting (Tohme et al., 1995). During the first millenium of domestication it is not impossible that the food shortage could have been frequent or that less pressure could be exerted from the Sunday market, and thus all genotypes were used for the pot (Debouck, 2017). It might be relevant to mention that the first millenium of $P$. vulgaris domestication in the central Andes happened without maize and without ceramic vessel (Debouck, 2016); the reactions by early domesticators vis-à-vis introgression with sympatric wild forms might have been different from current farmers' practices.

One should note that this pollen mediated gene flow between the crop and its wild ancestor and/or a closely related wild species is not restricted to Phaseolus beans but has taken (is still taking) place for several American crops (Table 3). It seems not restricted to the Americas either, as it has been mentioned to occur in other crops such as azuki bean (Vigna angularis) in Japan (Xu et al., 2000), pearl millet (Pennisetum glaucum) in Senegal (Pernès et al., 1984), rice (Oryza sativa) in Thailand (Ishikawa et al., 2006), and sorghum (Sorghum bicolor) in Sudan (Harlan, 1995). Other examples were provided by Heiser (1973). An explanation across species and locations (and times) might be in the fact that farmers usually do not select directly on the breeding systems of their crops but on traits related to the harvestable plant parts and/or related to the husbandry. But when that reproductive continuum is broken by distance [higher than $110 \mathrm{~m}$ in common bean: Zizumbo-Villarreal et al. (2005)] and/or 
by absence of synchronous flowering, the gene flow with the wild form is discontinued and only happens in the cultivated field. If so, the generated diversity will be related to the number of different genotypes in that field, the trend over the last century being to plant fewer and fewer of them. It is thus not surprising that some authors have noted the uniformity in the bean crop (Adams, 1977; Sonnante et al., 1994; Gioia et al., 2019).

\section{SECTION THREE: A TIME PERSPECTIVE FOR GENE FLOW IN THE GENUS Phaseolus}

The records presented in Tables 2, 3 may also imply a time perspective, although as a snapshot given the short time span for the observations made since Darwin time. Not only these many authors have observed gene flow in several bean species in different places, but also repeatedly over these past 160 years. But it may be for longer: Rendón-Anaya et al. (2017) have shown genomic introgressions from $P$. coccineus and $P$. dumosus into wild Mesoamerican P. vulgaris. Lobaton et al. (2018) reported the presence of a block of sequences of $P$. coccineus in chromosome 9 of a Guatemalan common bean landrace. Lioi and Hammer (1989) reported a unique phaseolin variant in wild P. vulgaris possibly resulting from introgression with $P$. coccineus. It is important to mention that when cultivated $P$. vulgaris and $P$. coccineus are planted side-by-side natural hybridization does occur (Rutger and Beckham, 1970). Long before humans entered the Americas through Beringia (Wells, 2003), a major natural crossing occurred in Central America: the genesis of $P$. dumosus. There, about 1-2 million years ago (Gepts et al., 2000), a wild $P$. vulgaris was crossed with $P$. coccineus, and backcrossed several times with $P$. coccineus and once with $P$. costaricensis (MinaVargas et al., 2016). From the wild ancestral form of $P$. dumosus restricted to montane forests of southern Guatemala (Freytag and Debouck, 2002), a weedy form arises. This weedy form that is harvested in the wild and also cultivated has been able to invade a habitat with more humid conditions and at high elevation, as compared to those of $P$. vulgaris and $P$. coccineus, as an indication

TABLE 3 | Cases of gene flow between the crop and its wild ancestor in the Americas.

\begin{tabular}{|c|c|c|}
\hline Crop species & $\begin{array}{l}\text { Country, } \\
\text { province }\end{array}$ & Source \\
\hline Cassava, Manihot esculenta & French Guiana & Duputié et al. (2007) \\
\hline $\begin{array}{l}\text { Chili pepper, Capsicum } \\
\text { annuum }\end{array}$ & Mexico, Sinaloa & $\begin{array}{l}\text { Hernández-Verdugo } \\
\text { et al. (2001) }\end{array}$ \\
\hline Corn, Zea mays & Mexico, Mexico & Warburton et al. (2011) \\
\hline $\begin{array}{l}\text { Cotton, Gossypium } \\
\text { barbadense }\end{array}$ & $\begin{array}{l}\text { Ecuador, } \\
\text { Galapagos }\end{array}$ & $\begin{array}{l}\text { Wendel and Percy } \\
\text { (1990) }\end{array}$ \\
\hline Potato, Solanum stenotomum & Peru, Cuzco & Rabinowitz et al. (1990) \\
\hline $\begin{array}{l}\text { Squash, Cucurbita } \\
\text { argyrosperma }\end{array}$ & Mexico, Jalisco & $\begin{array}{l}\text { Montes-Hernandez and } \\
\text { Eguiarte (2002) }\end{array}$ \\
\hline Sweet potato, Ipomoea batatas & $\begin{array}{l}\text { Central and N } \\
\text { South America }\end{array}$ & Roullier et al. (2013) \\
\hline Tomato, Solanum lycopersicum & Northern Andes & Blanca et al. (2012) \\
\hline
\end{tabular}

of invasiveness and novel ecological fitness. Interestingly, it shows resistance to fungi diseases such as anthracnose and white mold prevailing in these conditions (Hunter et al., 1982; Mahuku et al., 2002).

Gene flow has been present throughout the domestication process from the start some 8,000 years ago, in four out of the five cultivated species. One could anticipate a humble beginning not far from the wild form, possibly not in big acreages, and notably distant from the large areas where beans have been grown up to a recent past and today (Debouck, 2017). In spotty areas, the genic exchange with the original wild form was almost continuous, except when the material under domestication was moved out of the range of the wild form, thus allowing the reduction of antinutritional factors and the fixation of domesticated traits (Debouck, 2000). The extent of gene flow has been such that in the two species reported as preferentially autogamous, the common and the Lima beans, races or groups of cultivars have been recognized [Singh et al. (1991) and Westphal (1974), respectively]. It is that gene flow that resulted in the uniqueness of the races 'Durango' and 'Nueva Granada', away from their original places of domestication (Chacón et al., 2005); that uniqueness built up over centuries. At higher level in the organization of genetic diversity, the independent domestications and long genetic isolation have resulted in the hybrid weakness between the major gene pools (Singh and Gutiérrez, 1984; Gepts and Bliss, 1985), a genetically induced physiological disorder coming from the wild forms (Koinange and Gepts, 1992).

After 1493, P. vulgaris, P. lunatus and, to a lesser degree, $P$. coccineus were introduced in different parts of the Old World, as cultivated varieties for their edible seeds (Kaplan and Kaplan, 1992); P. acutifolius and P. dumosus were introduced into Africa only during the last century [Schmit and Baudoin (1987) and Molosiwa et al. (2014), respectively]. In the case of the former two, materials of the two original American gene pools were brought into new lands, and sometimes were grown together. In many places of eastern Africa mixtures were preferred over pure lines (Pickersgill, 1998). This planting of both gene pools happened most frequently in the case of common bean (Gepts and Bliss, 1988), less so for Lima bean because of different temperature requirements. Once again, farmers in these new homelands did not select on the reproductive system, and thus gene flow could happen, but this time between landraces, no more involving wild forms or wild species. The interest for recombinations between gene pools and beyond the incompatibility barriers has been motivated by the possibility of having the yield potential of Mesoamerican varieties while keeping the large seeds usually found in the Andean landraces, and secondary centers of diversity where the two gene pools are grown together may offer such recombinations. Thus, new variants identified at marker levels have been observed in Spain and Portugal (Santalla et al., 2002; Rodiño et al., 2006), Italy (Sicard et al., 2005; Raggi et al., 2013), the Netherlands (Zeven et al., 1999), central Europe (Angioi et al., 2010), Malawi (Khairallah et al., 1990), and China (Zhang et al., 2008). Gioia et al. (2013) have shown that many European landraces actually are recombinants between the two major gene pools, somehow 
reducing the original founder effect of domestication (stronger against the Mesoamerican gene pool because of the preference for larger seeds).

But the probabilities of finding interesting recombinants are related to durations of contact (and testing by farmers): three to five centuries in the Old World at the longest, while one could anticipate sixty or more centuries in Colombia and Brazil. Archaeological records report the presence of beans 8,700 years before present in the Middle Cauca valley of Colombia (Aceituno and Loaiza, 2014) and 6,000 years before present in the upper Madeira region of SW Amazonia of Brazil (Watling et al., 2018). Not surprisingly, the variation in gene pools in these two areas is significant (Gepts and Bliss, 1986; Beebe et al., 2001; Burle et al., 2010; Blair et al., 2013). Beyond molecular markers, which establish the inter-gene pool recombination nature of the materials, more studies are needed about their agronomic attributes, as they could save years in breeding. In this regard, in terms of seed iron content (for example G21242), the first results are promising (Islam et al., 2004). Another area from which important introgression has been reported is Chile (Paredes and Gepts, 1995), where a small - demographically speaking race originated (Singh et al., 1991). This race was confirmed on microsatellite loci evidence (Kwak and Gepts, 2009) and originated from wild forms of the southern Andes (BecerraVelásquez et al., 2011). In moving their favorite beans around the planet, humans brought the packed-in breeding systems, and local Hymenoptera quickly found their way to the nutritious nectar. Humans were not always inspired in pushing their practices toward uniformity, because novel variation and yield were served at low cost!

\section{SECTION FOUR: DYNAMICS OF WILD-WEEDY-CROP GENE FLOW IN THE COMMON BEAN}

It has been well documented that domestication brought a reduction of genetic diversity in crop plants, a phenomenon known as the founder effect of domestication (Ladizinsky, 1998). In the common bean, this effect was further severed by repeated introduction of landraces from the ancestral domestication areas to other places in the Americas in pre-Columbian times, and to other continents after Columbus (Gepts and Bliss, 1988; Gepts et al., 1988; Gioia et al., 2013). So, one can wonder how were bean landraces able to adapt to a large variety of agro-ecological environments in such circumstances? Part of the answer might be in the wild relatives.

Every time wild and landrace populations enter into contact, and given an adequate proximity, a proper environment and some overlapping in flowering times, potential for gene flow exists. Thanks to gene flow with wild relatives, landraces could acquire new alleles that may be relevant for adaptation processes (Rendón-Anaya et al., 2017). In this context, interbreeding wildweedy-crop complexes provide a mechanism by which alleles may be interchanged between the different elements of the complex and thus their genetic composition may be altered (Van Raamsdonk and Van Der Maesen, 1996). In this section, we review the distribution and the characteristics of these complexes in common bean in Mesoamerica and the Andes with the aim of illustrating their importance in shaping the genetic structure of wild and domesticated populations and giving recommendations for future studies.

Table 4 summarizes some of the main features of wild-weedycrop complexes of common bean in Mesoamerica and the Andes. In these complexes, wild beans are defined as those having indeterminate vines of $2-3 \mathrm{~m}$ long, strongly dehiscent pods and small seeds (3.6-6.2 g per hundred seeds for Mesoamerican types and 6-14 $\mathrm{g}$ for Andean types) of solid shiny black color or brown speckled pattern with tiny black stripes and/or spots. Weedy types are defined as those having larger seeds (9-11 g per hundred seeds for Mesoamerican types and around $18 \mathrm{~g}$ for Andean types) with solid black or speckled with gray, beige or tan background with longer and highly dehiscent pods. Wild and weedy types are usually found in disturbed habitats and sometimes in agricultural habitats among the cultivated plants. Domesticated types hold typical traits of the domestication syndrome as larger seeds (around $21 \mathrm{~g}$ per hundred seed for Mesoamerican types and around 40-65 g for Andean types), seeds of varied color patterns, larger and mostly indehiscent pods, sometimes show determinate growth habit and are found in cultivated fields.

The presence of wild-weedy-crop complexes in common bean has been mainly determined by the observation that the different components of the complex grow next to each other or within a radius of a few kilometers, and by the presence of segregating or stabilized intermediate forms between domesticated and wild types (e.g., types showing highly dehiscent pods and pod length and seed color typical of landraces) (Beebe et al., 1997). For example, in Oaxaca, Mexico, Acosta Gallegos et al. (1994) found a wild population growing on the margins of 'milpas' along with maize, cultivated common bean and squashes and in nearby disturbed open habitats. Intermediate forms, on the basis of seed traits, were found growing in mixture with wild beans. In one collection trip carried out in Guatemala, Debouck (1995) observed, among the wild seeds harvested from one population in Quetzaltenango, the presence of seed types that suggested introgression from common bean landraces grown nearby (these seeds were either larger with wild color pattern or small with solid color). In Costa Rica, Debouck et al. (1989a) reported wild P. vulgaris populations in two places in the province of San José. In both wild populations, the authors observed escaped forms with brown speckled grayish seeds of larger size (around $15 \mathrm{~g}$ per 100 seeds), which suggested introgression from landraces. In Ecuador, Debouck et al. (1989b) observed two weedy populations growing close to one wild bean population in Girón, Azuay. The seeds of these weedy populations showed some influence of cultivated types; however, no cultivated beans were found in the close vicinity. Meanwhile, Beebe et al. (1997) found in Colombia and Peru, weedy stabilized genotypes that displayed traits of both wild and domesticated types, as well as segregating populations, which were indicative of the persistence of these complexes over time. Also, the predominance of local wild phaseolin types (in contrast to introduced phaseolin types) among all the components of the complexes in Peru and Colombia showed the ancient evolution of these complexes. In Bolivia, Debouck 
TABLE 4 | Wild-weedy-crop complexes reported in common bean in Mesoamerica and the Andes.

\begin{tabular}{|c|c|c|c|c|c|c|}
\hline Country & Place and number of complexes & $\begin{array}{l}\text { Date of } \\
\text { study }\end{array}$ & Habitat & Direction of gene flow & Traits studied & References \\
\hline Mexico & $\begin{array}{l}\text { Santo Domingo de Albarradas, } \\
\text { county of Tlacoluca de Matamoros, } \\
\text { state of Oaxaca (one complex: } 96^{\circ} \\
16^{\prime} \mathrm{W}, 17^{\circ} 04^{\prime} \mathrm{N}, 1480 \text { masl). }\end{array}$ & $\begin{array}{l}\text { 18th } \\
\text { December } \\
1993\end{array}$ & $\begin{array}{l}\text { Wild types were found in open, } \\
\text { sunny, disturbed habitats and in } \\
\text { cultivated fields called milpas. } \\
\text { Weedy types were found growing in } \\
\text { mixture with wild beans in milpas } \\
\text { and nearby areas. Elevation } \\
\text { between } 1460 \text { and } 1500 \text { masl. }\end{array}$ & Not formally tested & $\begin{array}{l}\text { Morphological traits, mainly seed } \\
\text { size and color pattern, pod length } \\
\text { and pod dehiscence. }\end{array}$ & $\begin{array}{l}\text { Acosta } \\
\text { Gallegos } \\
\text { et al. (1994) }\end{array}$ \\
\hline Guatemala & $\begin{array}{l}\text { Progreso, San Agustín } \\
\text { Acasaguastlán (one complex: } 89^{\circ} \\
\left.56^{\prime} \mathrm{W}, 15^{\circ} 04^{\prime} \mathrm{N}, 1,250 \mathrm{~m}\right)\end{array}$ & $\begin{array}{l}\text { December } \\
1987\end{array}$ & $\begin{array}{l}\text { Wild and weedy populations found } \\
\text { on border of maize field in pine oak } \\
\text { forest }\end{array}$ & Not tested & $\begin{array}{l}\text { In contrast to the wild form (with } \\
\text { small black-speckled seeds with } \\
\text { gray background), the weedy form } \\
\text { had larger solid black seeds. }\end{array}$ & $\begin{array}{l}\text { Debouck } \\
\text { (1995) }\end{array}$ \\
\hline Guatemala & $\begin{array}{l}\text { Quezaltenango, Zunil (one complex: } \\
91^{\circ} 31^{\prime} \mathrm{W}, 14^{\circ} 45^{\prime} \mathrm{N}, 1,760 \mathrm{~m} \text { ). }\end{array}$ & $\begin{array}{l}\text { 20-26th } \\
\text { January } \\
1995\end{array}$ & $\begin{array}{l}\text { Wild population found in lower } \\
\text { montane forest }\end{array}$ & Not formally tested. & $\begin{array}{l}\text { Seed traits: presence of larger } \\
\text { seeds with wild seed phenotypes } \\
\text { and small seeds with solid colors, } \\
\text { among the seed harvested from } \\
\text { wild population }\end{array}$ & $\begin{array}{l}\text { Debouck } \\
\text { (1995) }\end{array}$ \\
\hline Costa Rica & $\begin{array}{l}\text { San José, Aserri (one complex: } 84^{\circ} \\
\left.07^{\prime} \text { W, } 09^{\circ} 52^{\prime} \mathrm{N}, 1,560 \mathrm{~m}\right)\end{array}$ & $\begin{array}{l}\text { January } \\
1987\end{array}$ & $\begin{array}{l}\text { Premontane humid forest, two wild } \\
\text { populations were found at } 1750 \\
\text { and } 1560 \text { masl. }\end{array}$ & Not formally tested. & $\begin{array}{l}\text { In both wild populations, escaped } \\
\text { forms were observed with larger } \\
\text { seeds (around } 15 \mathrm{~g} \text { per } 100 \text { seeds) } \\
\text { with brown speckled grayish seeds. }\end{array}$ & $\begin{array}{l}\text { Debouck } \\
\text { et al. } \\
\text { (1989a) }\end{array}$ \\
\hline Colombia & $\begin{array}{l}\text { Department of Cundinamarca (six } \\
\text { complexes: Choachí, } 73^{\circ} 55^{\prime} \mathrm{W}, 4^{\circ} \\
33^{\prime} \mathrm{N}, 1,750 \mathrm{~m} ; 73^{\circ} 54^{\prime} \mathrm{W}, 4^{\circ} 33^{\prime} \\
\mathrm{N}, 2,040 \mathrm{~m} ; 73^{\circ} 54^{\prime} \mathrm{W}, 4^{\circ} 31^{\prime} \mathrm{N}, \\
1,795 \mathrm{~m} ; 73^{\circ} 55^{\prime} \mathrm{W}, 4^{\circ} 35^{\prime} \mathrm{N}, \\
1,810 \mathrm{~m} \text {; Fómeque, } 73^{\circ} 54^{\prime} \mathrm{W}, 4^{\circ} \\
31^{\prime} \mathrm{N}, 1,690 \mathrm{~m} \text {; Pacho, } 74^{\circ} 11^{\prime} \mathrm{W} \text {, } \\
5^{\circ} 11^{\prime} \mathrm{N}, 1,580 \mathrm{~m} \text { ). Department of } \\
\text { Boyacá (two complexes: Tenza, } \\
73^{\circ} 26^{\prime} \mathrm{W}, 5^{\circ} 04^{\prime} \mathrm{N}, 1,500 \mathrm{~m} ; 73^{\circ} \\
26^{\prime} \mathrm{W}, 5^{\circ} 04^{\prime} \mathrm{N}, 1,460 \mathrm{~m} \text { ). }\end{array}$ & $\begin{array}{l}\text { February } \\
1992 \text { and } \\
\text { January } \\
1993\end{array}$ & $\begin{array}{l}\text { Wild and weedy types were found } \\
\text { in habitats disturbed by agricultural } \\
\text { activities and grazing, on the } \\
\text { western slope of the Cordillera } \\
\text { Oriental. Some weedy types were } \\
\text { found in coffee groves and maize or } \\
\text { sugarcane fields. Landraces were } \\
\text { collected mostly from farmer's seed } \\
\text { stocks. Elevation between } \\
\text { 1460-2040 masl. }\end{array}$ & $\begin{array}{l}\text { Not formally tested, but some } \\
\text { suggestive data were obtained. } \\
\text { Direction from domesticated to } \\
\text { wild, evidenced by: (1) wild types } \\
\text { introgressed with domesticated } \\
\text { traits (pod length and grain color). } \\
\text { (2) Presence of an Andean } \\
\text { phaseolin type ('T') in a wild } \\
\text { population suggests introgression } \\
\text { from Andean introduced landraces. } \\
\text { Direction from wild to domestication } \\
\text { evidenced by: (1) the presence of } \\
\text { wild Colombian phaseolins ('B' and } \\
\text { 'L') in landraces. (2) Brown, } \\
\text { greenish-gray or gray-striped colors } \\
\text { seeds or very small seeds present } \\
\text { in cultivated material. }\end{array}$ & $\begin{array}{l}\text { Morphological traits of seeds (seed } \\
\text { size and color pattern), and pod } \\
\text { (length and dehiscence). Also } \\
\text { phaseolin types. }\end{array}$ & $\begin{array}{l}\text { Beebe } \\
\text { et al. (1997) }\end{array}$ \\
\hline Ecuador & $\begin{array}{l}\text { Azuay, Girón (one complex: } 79^{\circ} 11^{\prime} \\
\text { W, } 03^{\circ} 12^{\prime} \mathrm{S}, 1,930 \mathrm{~m} \text { ) }\end{array}$ & June 1989 & $\begin{array}{l}\text { Two wild populations found on } \\
\text { disturbed thicket vegetation in low } \\
\text { montane dry forest. Two weedy } \\
\text { populations were found growing } \\
\text { near the wild population at Girón, } \\
\text { Azuay. Absence of cultivated beans } \\
\text { in the close vicinity. }\end{array}$ & Not formally tested. & $\begin{array}{l}\text { Seed traits. One weedy type with } \\
\text { larger seeds and the other weedy } \\
\text { type with tiny solid black seeds. }\end{array}$ & $\begin{array}{l}\text { Debouck } \\
\text { et al. } \\
\text { (1989b) }\end{array}$ \\
\hline
\end{tabular}


TABLE 4 | Continued

\begin{tabular}{|c|c|c|c|c|c|c|}
\hline Country & Place and number of complexes & $\begin{array}{l}\text { Date of } \\
\text { study }\end{array}$ & Habitat & Direction of gene flow & Traits studied & References \\
\hline Peru & $\begin{array}{l}\text { Department of Apurimac (five } \\
\text { complexes: Abancay, Circa, } 72^{\circ} \\
58^{\prime} \mathrm{W}, 13^{\circ} 51^{\prime} \mathrm{S}, 2,050 \mathrm{~m} \text {; } \\
\text { Abancay, Abancay, } 72^{\circ} 54^{\prime} \mathrm{W}, 13^{\circ} \\
39^{\prime} \mathrm{S}, 2340 \mathrm{~m} \text {; Andahuaylas, } \\
\text { Ocobamba, } 73^{\circ} 28^{\prime} \mathrm{W}, 13^{\circ} 33^{\prime} \mathrm{S} \text {, } \\
2,760 \mathrm{~m} \text {; Andahuaylas, Kishuara, } \\
73^{\circ} 12^{\prime} \mathrm{W}, 13^{\circ} 37^{\prime} \mathrm{S}, 2,440 \mathrm{~m} \text {; } \\
\text { Abancay, Quillabamba, } 72^{\circ} 52^{\prime} \mathrm{W} \text {, } \\
13^{\circ} 37^{\prime} \mathrm{S}, 2,580 \mathrm{~m} \text { ) Department of } \\
\text { Cusco (three complexes: Anta, } \\
\text { Limatambo, } 72^{\circ} 25^{\prime} \mathrm{W}, 13^{\circ} 28^{\prime} \mathrm{S} \text {, } \\
2,460 \text { m; Paruro, Colcha, } 71^{\circ} 51^{\prime} \\
\text { W, } 13^{\circ} 48^{\prime} \mathrm{S}, 2,940 \mathrm{~m} \text {; Paruro, } \\
\text { Paccarectambo, } 72^{\circ} 04^{\prime} \mathrm{W}, 13^{\circ} \\
52^{\prime} \mathrm{S}, 2,560 \mathrm{~m} \text { ) }\end{array}$ & $\begin{array}{l}\text { May } 1987 \\
\text { and May } \\
1988\end{array}$ & $\begin{array}{l}\text { Wild populations were found in dry } \\
\text { shrubs and thickets in deep } \\
\text { inter-Andean valleys nearby } \\
\text { cultivated fields. Landraces were } \\
\text { found in cultivated fields or were } \\
\text { obtained from farmer's seed } \\
\text { stocks. Elevation between } \\
2,000-3,000 \text { masl. Bean landraces } \\
\text { were found cultivated along with } \\
\text { maize and squash in traditional } \\
\text { chacra agriculture. }\end{array}$ & $\begin{array}{l}\text { Not formally tested, but some } \\
\text { suggestive data were obtained. } \\
\text { Direction from domesticated to } \\
\text { wild, evidenced by: (1) larger seed } \\
\text { size of wild types. (2) In some } \\
\text { cases, the presence of spots } \\
\text { around the hilum, typical of } \\
\text { landraces, observed in wild seeds. } \\
\text { (3) The presence of Mesoamerican } \\
\text { 'S' phaseolin in weedy types. }\end{array}$ & $\begin{array}{l}\text { Morphological traits of seeds (seed } \\
\text { size and color pattern), and pod } \\
\text { (length and dehiscence). Also } \\
\text { phaseolin types. }\end{array}$ & $\begin{array}{l}\text { Beebe } \\
\text { et al. (1997) }\end{array}$ \\
\hline Peru & $\begin{array}{l}\text { Junín, Huacapistana (one complex: } \\
75^{\circ} 32^{\prime} \mathrm{W}, 11^{\circ} 14^{\prime} \mathrm{S}, 2,110 \mathrm{~m} \text { ) }\end{array}$ & & & & & $\begin{array}{l}\text { Debouck } \\
\text { et al. } \\
\text { (1989c) }\end{array}$ \\
\hline Bolivia & $\begin{array}{l}\text { Tarija, Tabladita (two complexes: } \\
64^{\circ} 45^{\prime} \mathrm{W}, 21^{\circ} 32^{\prime} \mathrm{S}, 1,890 \mathrm{~m} \text { ). }\end{array}$ & $\begin{array}{l}\text { April-May } \\
1988 \text { May } \\
1994\end{array}$ & $\begin{array}{l}\text { Wild beans were found in } \\
\text { inter-Andean valleys in humid } \\
\text { temperate forests, dry temperate } \\
\text { forests and low montane dry forest. } \\
\text { Weedy forms were found on } \\
\text { thickets and within a maize field } \\
\text { along with cultivated beans. }\end{array}$ & Not tested. & $\begin{array}{l}\text { Observations were made mainly on } \\
\text { seed types: weedy types had } \\
\text { intermediate seed sizes (around } \\
20.4 \text { and } 49.2 \mathrm{~g} \text { per } 100 \text { seeds) } \\
\text { with brown speckled grayish and } \\
\text { brownish black-spotted seeds. } \\
\text { Landraces were of three types: } \\
\text { large-seeded beans for } \\
\text { consumption, beans consumed } \\
\text { after toasting and beans used for } \\
\text { play. }\end{array}$ & $\begin{array}{l}\text { Debouck } \\
\text { (1988, } \\
1994)\end{array}$ \\
\hline
\end{tabular}


(1994) found in Tarija two weedy populations growing within a radius of $5 \mathrm{~km}$ from a wild population, one of them growing on thickets and the other one growing within a maize field along with cultivated beans. The seed characteristics of these weedy types suggested natural hybridizations between wild and cultivated populations.

The direction of gene flow has been inferred on the basis of morphological traits and biochemical (e.g., phaseolin type) and molecular markers for a handful of these complexes, therefore this is a subject that deserves more attention. Here we describe some studies that not only show the direction of gene flow but also its impact on genetic diversity. Beebe et al. (1997) found the ' $\mathrm{T}$ ' phaseolin in a wild population from the Colombian Andes and as this phaseolin type is typical of wild populations from central-southern Andes and their domesticated counterparts, the authors explained this finding as a result of introgression of phaseolin $\mathrm{T}$ from introduced Andean landraces. Phaseolin was also useful for the authors to describe gene flow in the opposite direction, namely from wild to landrace populations, when they observed the presence of ' $\mathrm{B}$ ' phaseolin, typical of wild populations from Colombia, in medium-large seeded Mesoamerican landraces. Phaseolin was also useful to document cases of introgression between Mesoamerican and Andean landraces as evidenced by the presence of Andean phaseolin types in small-seeded Mesoamerican landraces in central Colombia where these landraces are often grown in mixtures. In centralwestern Mexico, Zizumbo-Villarreal et al. (2005) studied the genetic structure of three complexes by means of seed mass and three dominant molecular markers (ISSR). In all the complexes, the authors found that genetic diversity in wild populations was equal or even lower than the one found in domesticated populations within its own complex. This larger diversity in landraces was explained as a result of farmers' practices such as regional seed interchange and cultivation of a large mixture of landraces within each plot. In one of the complexes, the wild population showed a closer genetic relationship to the weedy and domesticated populations within its own complex than to other wild populations of the region, a result that was interpreted as indicative of a predominance of gene flow from domesticated to wild populations. A similar result was reported by Papa and Gepts (2003) in a study of gene flow in wild and domesticated populations of common bean in Mexico by means of AFLP markers. An admixture analysis suggested that gene flow is asymmetric and is more prominent from domesticated to wild populations, which was explained by differences in population size (pollen from domesticated populations is more prominent than wild populations) and by the negative selection that farmers may make against domesticated seeds showing signs of introgression from wild types. This asymmetric gene flow has also been shown by a genome-wide analysis carried out by Rendón-Anaya et al. (2017). The authors found that the length of introgressed tracks in the genome was larger in the direction domesticated to wild than in the opposite direction.

In plants, genetic structure comparisons made on the basis of molecular markers with different modes of inheritance (biparental, paternal and maternal) are key to reach a more comprehensive understanding on how seed and pollen movement mediate intraspecific (McCauley, 1994; Arnaud et al., 2003; Du et al., 2011; Mandel et al., 2016) and interspecific gene flow (Desiderio et al., 2013; Rendón-Anaya et al., 2017). In spite of this, in the common bean these types of comparisons have been very scarce. In one of these studies, Chacón et al. (2005) analyzed the chloroplast DNA haplotype (cpHp) diversity in wild and domesticated common beans. The authors found that only a single chloroplast haplotype was present in the Andean races (Nueva Granada, Peru and Chile) while the Mesoamerican races (Durango, Mesoamerica, Jalisco, and Guatemala) differed in their chloroplast haplotypes (cpHps). Independent evidence mainly based on nuclear DNA markers have shown that the common bean was domesticated only once in Mesoamerica (Kwak et al., 2009). Under this hypothesis, the presence of multiple cpHps among the Mesoamerican races was partly explained by the authors as a result of multiple events of chloroplast capture from local wild populations. Because chloroplast DNA is maternally inherited, chloroplast capture will require that hybrids resulting from wild (pollen receptor) $\mathrm{x}$ domesticated (pollen donor) crosses (and that therefore contain the cpHp from the wild population) experience repeated backcrossing with pollen from the landrace population. Lategeneration hybrids will resemble more the landrace population but will keep the cpHp of the sympatric wild population and maybe other traits relevant for adaptation to local conditions. In another study, González Torres et al. (2004) found in wild common bean populations from Costa Rica, cpHps typical of landraces, a pattern that was interpreted by the authors as possible gene flow events through chloroplast capture from introduced landraces.

Despite the importance of wild-weedy-crop complexes, several studies have shown that the persistence and preservation of these complexes largely depends on the use that farmers make of them and may be at risk. For example, Beebe et al. (1997) reported that farmers in Peru consume grains harvested from all the components of the complex as green or dry beans, while the commercial variety that they grow is sold in the market. The authors also reported that in Colombia farmers distinguish and give different names to wild and weedy types ('pajarito' and 'copetón', respectively), and in some cases farmers tolerate bean weedy types among their maize fields for selfconsumption, while wild bean types are neglected most of the time. In Mexico, Zizumbo-Villarreal et al. (2005) reported that in the three complexes that they studied farmers were able to distinguish the weedy types and that farmers protected them because weedy types were more resistant to different types of stresses such as drought, excessive wet periods and fungi attacks. These observations suggest that one of the consequences that these complexes may bring is the introduction of adaptive traits among the different components of the complex. In this respect, Beebe et al. (1997) called attention to the fact that, in Colombia, weedy types are widely distributed, even in regions where wild populations have not yet been collected. The authors argued that the broad adaptation shown by weedy types might have been derived from genes present in landraces. In this context, the authors stated that the preservation of these complexes would depend at the end on the value that can be 
derived from the variability generated in them. In this regard, genome-wide analyses as the ones carried out by Rendón-Anaya et al. (2017) are highly relevant not only to document cases of genomic introgressions in both wild and domestic populations but to show the value of these introgressions, for example to allow the adaptation of landraces to diverse agro-ecological environments. Today, genomic tools are available to document the genetic footprints of introgressions and this subject will be addressed below.

\section{SECTION FIVE: WILD-WEEDY-CROP GENE FLOW IN LIMA BEAN FROM THE PENINSULA OF YUCATAN, MEXICO}

In Mexico, wild Lima beans are distributed on the Pacific slope, the Gulf of Mexico, the Yucatán Peninsula and, to a lesser extent, in some areas along the Central Neovolcanic axis (Andueza-Noh et al., 2016). On the other hand, cultivated Lima beans have a restricted distribution toward the south-southeast of Mexico, where it is part of the traditional agriculture of the ethnic groups present there (Ballesteros, 1999). One region of Mexico where wild and cultivated populations grow sympatrically is the Yucatán Peninsula (Martínez-Castillo et al., 2004). In this region, Lima bean landraces are known in Maya as Ib or Ibe (although each of these has a specific name in the Mayan language) and wild Lima bean is known as Ib-cho (ib of mouse). While Ib-cho is inedible due to the high content of cyanogenic glycosides (linamarin) of its seeds (Baudoin et al., 1991), Ib represents the fourth most important crop within the traditional Mayan slash and burn farming system known as milpa (Martínez-Castillo et al., 2004).

The sympatric growth of wild and cultivated Lima bean populations in the Yucatán Peninsula, as well as the high outcrossing rates (Baudoin et al., 1998; Penha et al., 2017) and the generation of soil seed banks by the wild populations with a 3-year viability (Degreef et al., 2002), allow the existence of wild-weedy-crop gene flow, which represents one of the main micro-evolutionary forces that affect the diversity and genetic structure of domesticated species (Ellstrand et al., 1999). In the Yucatán Peninsula, the probability of wild-weedy-crop gene flow events increases as a result of some characteristics of the Mayan milpa, such as: (1) its itinerancy, which favors contact between wild and domesticated populations, (2) fire management, which helps in the regeneration of wild populations from the seed banks generated by them, (3) manual weeding, which allows wild plants to regenerate and reach reproductive stage, (4) rest periods of the plot of up to 20 years, which allows the regeneration and maintenance of wild populations, and (5) production for auto-consumption, which promotes more relaxed seed selection criteria that allow the maintenance of introgressed seeds. All the aforementioned make the Yucatán Peninsula a natural laboratory to study the wild-weedy-crop gene flow in Lima bean, a process that could be very old considering the finding of seed remains with domesticated traits in Yucatan with an age of at least 1000 years before present (Kaplan, 1965). The existence of wildweedy-crop gene flow could be one of the reasons why this

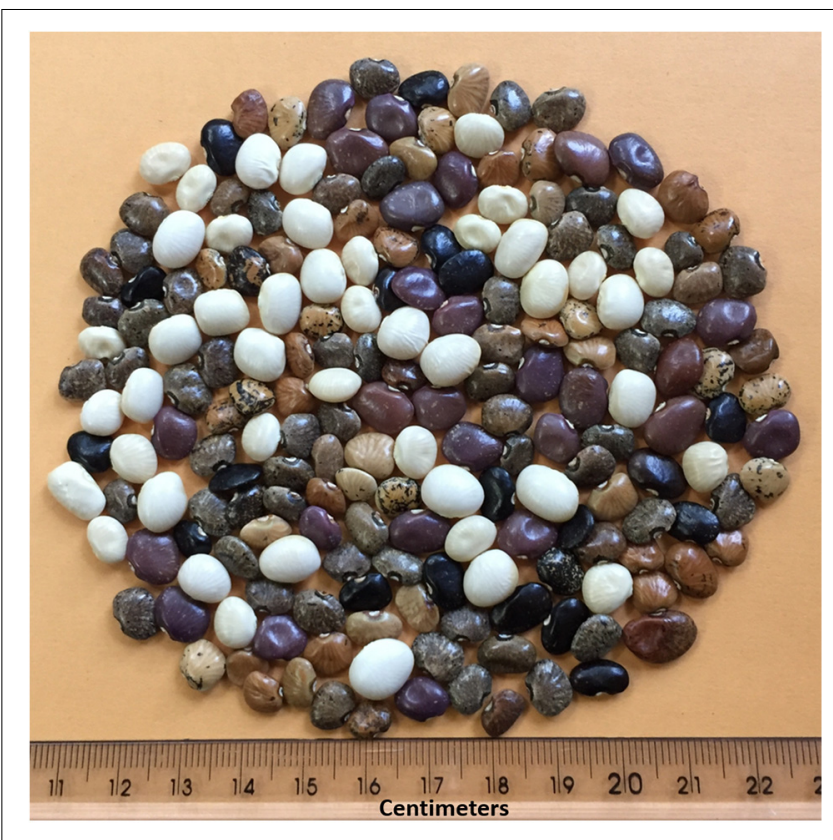

FIGURE 7 | Seeds collected in a wild-weedy-crop inter-reproductive complex located in a 2 year's old milpa from Campeche, Mexico. In this milpa, only Sac-lb landrace (with round-white seeds) was planted.

region has the greatest number of landraces in the entire Mexico (Ballesteros, 1999), including more than 30 reported landraces (Martínez-Castillo et al., 2004).

The first evidence of wild-weedy-crop gene flow in Lima bean from the Yucatán Peninsula came from morphological information (Figure 7). Martínez-Castillo et al. (2004) reported the collection of domesticated Lima bean plants with wild characteristics (small purple flowers, small seeds and pods). Martínez-Castillo et al. (2006) reported two wild populations of Lima beans with plants that presented morphological characteristics similar to those observed in some landraces (i.e., large white flowers, large pods and seeds). Martínez-Castillo et al. (2008) collected seeds with wild characteristics within a barn (Figure 8). Although these characteristics indicated that they were not edible, the family who owned these seeds reported consuming them and indicated they planted the seeds in their home garden to protect them, two aspects that suggest an incipient domestication process. The authors of that work pointed out that the management of mixtures of seeds in Lima bean (i.e., lots with seeds of different colors, shapes and sizes, as a result of the mixture of various landraces) by Mayan farmers and their production for auto-consumption, are factors that could mask the presence of weedy seeds, thus favoring entry of wild genes into the domesticated gene pool.

If the Lima bean cultivation has occurred for a very long time in the Yucatán Peninsula, this could have allowed wild and cultivated populations to become in contact on multiple occasions, thus generating gene flow events. Hence, the Yucatán Peninsula could be considered as a large wild-weedy-crop 


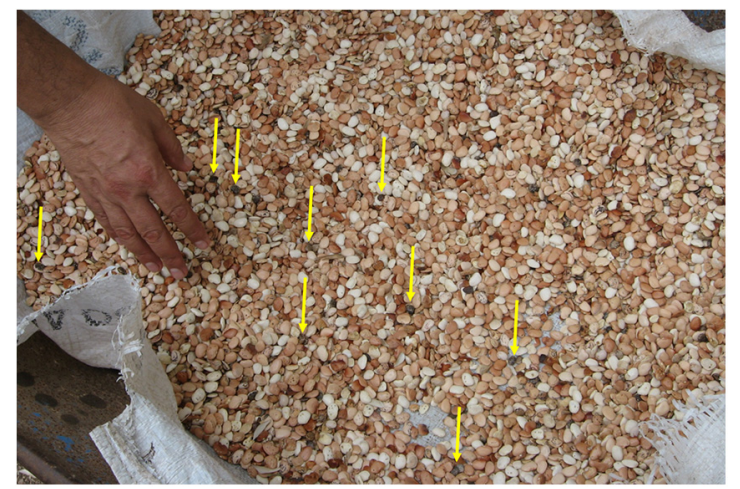

FIGURE 8 | Seeds of Lima bean with wild characteristics collected in a barn from Quintana Roo, Mexico. Yellow arrows point to these seeds.

complex for this species. Using nine microsatellite loci, MartínezCastillo et al. (2007) analyzed the magnitude and direction of wild-weedy-crop gene flow in Lima bean from four traditional agricultural regions of the Yucatán Peninsula. Coefficients of estimated ancestry, obtained with the STRUCTURE program, showed low levels of recent gene flow between wild and cultivated populations (Figure 9), both at the Peninsula level and within the four agricultural regions. However, the authors also reported the finding of a wild population where the 20 individuals analyzed presented an intermediate wild-weedy-crop ancestry. This population was collected in the area of the Ruins of Itzinte, in the northeast of Campeche, a place where the so-called continuous milpa is practiced (in this type of milpa, there is no rest period for the plot) and where Lima bean has been cultivated for many years. The authors also reported two other wild populations that presented individuals with high percentages of cultivated ancestry (Figure 9). These three populations are weedy populations and they can function as a genetic bridge between the wild and cultivated populations; thus, favoring processes of gene flow and introgression between both gene pools. The authors also reported low levels of historical wild-weedy-crop gene flow in the Peninsula $(\mathrm{Nm}=0.44)$ and within agricultural regions $(\mathrm{Nm}=0.31-0.51)$, but that gene flow was asymmetric, threefold higher from the cultivated populations toward the wild ones. Interestingly, although the existence of wild-weedy-crop gene flow events in Lima bean seem to be a common process in the region, and maybe have been occurring for more than 1000 years, there is a marked genetic structure in the Yucatán Peninsula that clearly differentiates the wild gene pool from the cultivated one.

Another approach to evaluate wild-weedy-crop gene flow in the Lima bean from the Yucatán Peninsula is directly to study the milpas where contact between wild and domesticated populations is currently occurring. Even though the interaction between these populations seems to be a common event in this region, the itinerant nature of the Mayan milpa does not facilitate its discovery. Dzul-Tejero et al. (2014), using 12 microsatellite loci, evaluated levels of introgression and their impact on the genetic diversity of Lima bean in three milpas where wild and cultivated plants grew. Using the STRUCTURE program, these authors reported substantial differences in the degree of introgression of the milpas studied (Figure 10). The milpa with the lowest degree of introgression was the Xocen milpa in which the farmer clearly recognized the introgressed seeds and carried out selection against them. This farmer asserted that the "mixture" of Ibcho with his Ibes caused a bitter taste in the seeds preventing him from selling his production. In contrast, the milpa showing the highest level of introgression was the X-Hazil milpa where the farmer selected and kept the introgressed seeds, which were part of his diet and not for commercialization. The authors also reported higher levels of genetic diversity in the cultivated gene pool of the X-Hazil milpa $\left(H_{E}=0.21\right)$, compared to the cultivated gene pool of the Xocen milpa $\left(H_{E}=0.02\right)$; this result highlights the importance of gene flow and introgression as processes that can increase the levels of genetic diversity in domesticated species.

In conclusion, studies carried out in the Yucatán Peninsula indicate that wild-weedy-crop gene flow events are common in Lima bean, although not always easy to locate; while the antiquity of the crop suggests that these events have been taking place for more than 1000 years. However, at present there is a clear genetic differentiation between wild and cultivated populations as result, in part, of the selfing tendency of the species. Also, Mayan farmers play a very important role in favoring or preventing wild-weedycrop gene flow, which occurs through aspects such as tolerance or not- of wild plants, seed selection criteria, manual weeding and the destination of production, among others. Since the Mayan milpa has not escaped the process of agricultural intensification (reflected in the reduction of the rest period, increase in the use of herbicides and fertilizers, and production focused on the market), wild-weedy-crop gene flow events are more common in milpas that receive a more traditional management. It is also in these milpas where the impact of wild-weedy-crop gene flow on the genetic diversity of the cultivated gene pool of Lima bean may be greater.

\section{SECTION SIX: GENOMIC FOOTPRINTS OF INTROGRESSION IN Phaseolus SPECIES}

Due to the high level of inbreeding observed in Phaseolus species, cultivars of the different domesticated species tend to have low heterozygosity and be stratified in clearly defined populations. Current high throughput sequencing technologies allow to obtain genome wide genetic information across gene pools, which can be used to identify the introgressed haplotype segments resulting from both ancient and modern admixture events across gene pools and even species. In this section we will review different genomic resources produced in the last few years for Phaseolus species, including genome assemblies, whole genome resequencing and genotyping-by-sequencing of populations, focusing on the use of these resources to document the genetic footprint of introgression events among landraces and modern cultivars.

Currently available genome assemblies for Phaseolus species are focused on common bean. A chromosome-level genome 


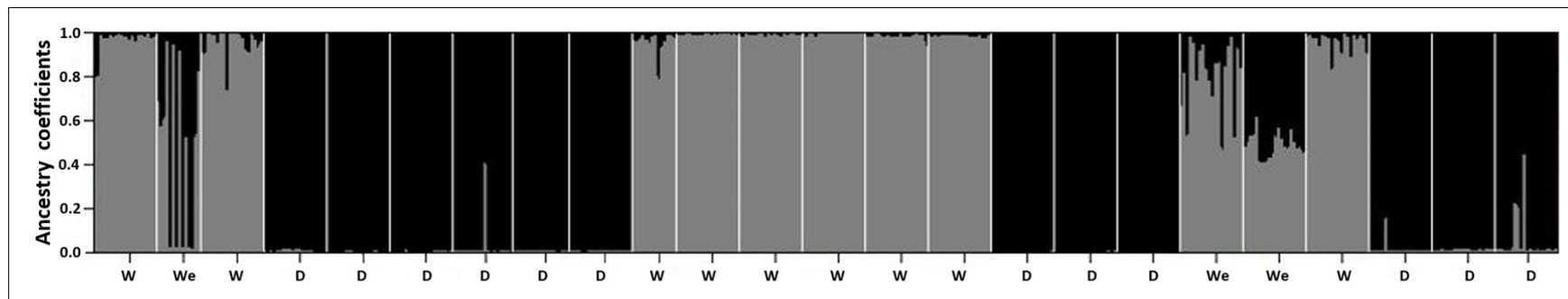

FIGURE 9 | Coefficients of estimated ancestry per individual of 12 cultivated (D), 9 wild (W), and 3 weedy (We) populations of Lima beans from Yucatán Peninsula, Mexico, using 9 microsatellite loci and the Structure program. Each individual is represented by a single vertical line broken into two colored segments (wild, gray; cultivated, black), with lengths proportional to the individual's estimated ancestry fraction from each of the two biological statuses. A wild population was considered as weedy when it had $20 \%$ or more ancestry from the cultivated gene pool. Modified from Martínez-Castillo et al. (2007).

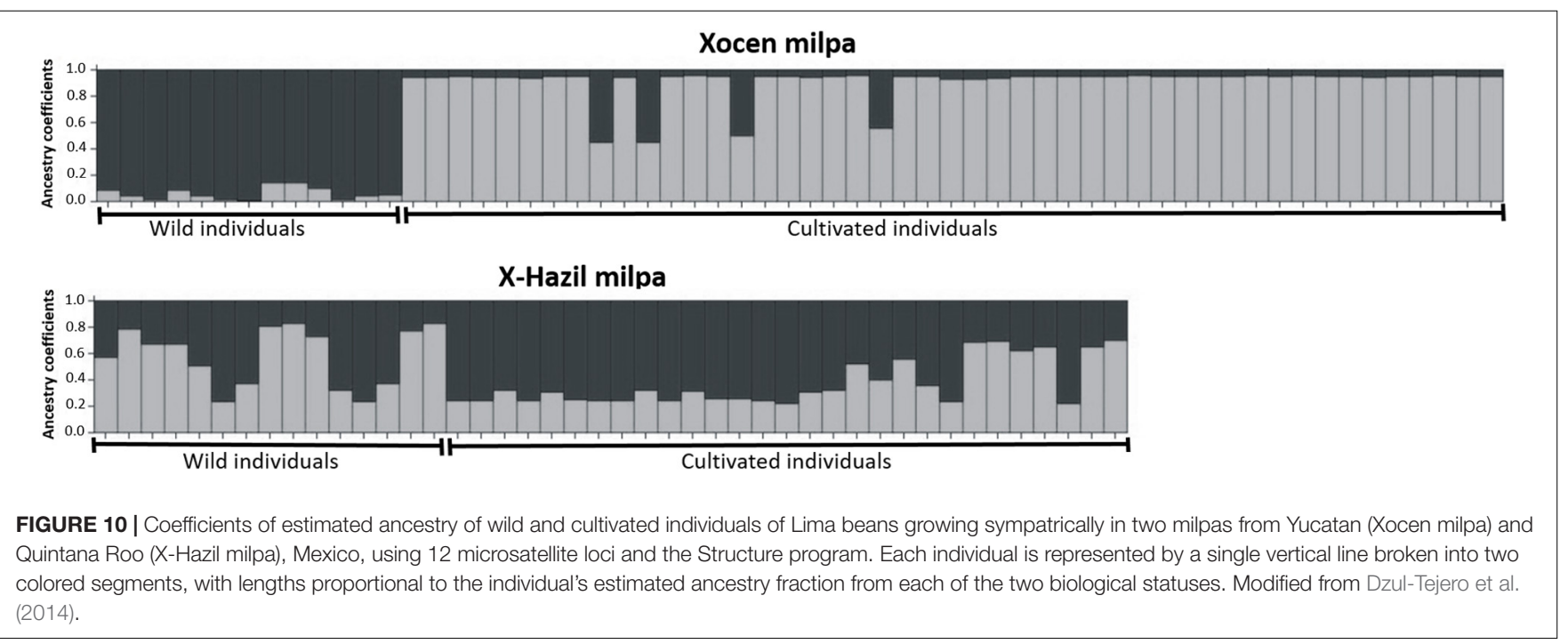

assembly of the Andean landrace G19833 was first generated combining different short read technologies, and integrating markers from genetic maps (Schmutz et al., 2014). This genome is widely used as a reference for the species and has been reassembled based on long PacBio reads. A draft genome assembly of the Mesoamerican cultivar BAT93 was also made available by Vlasova et al. (2016). Although chromosome-level assembly was not achieved in this case and then major structural variation with G19833 could not be identified, this study includes a complete analysis of gene evolution, focused on genes expressed at different stages of the developmental process. A third genome assembly of the Durango race cultivar UI111 is currently available at LIS and Phytozome. Regarding other Phaseolus species, our research group recently made available in Phytozome the genome of the P. lunatus accession G27455 (Garcia et al., 2021). Although information of introgressed segments cannot be inferred directly for assemblies of individual accessions, these assembled genomes are critical as tools to guide the analysis of population genomics data obtained from different protocols based on Illumina sequencing.

Regarding whole genome resequencing (WGS), a first set of 17 Andean and Mesoamerican varieties of common bean was sequenced at low average read depth (below 5X) with the goal of building a molecular tool for genotyping (Song et al.,
2015). A recent example of the use of this tool is the study of Almeida et al. (2020) in which the genotypic information allowed to identify Andean introgressions in Mesoamerican accessions cultivated in Brazil. The data from this study was integrated with WGS of 37 additional accessions sequenced at a larger average read depth ( $7 \mathrm{X}$ to $15 \mathrm{X}$ ) (Lobaton et al., 2018). The main outcome of this work was the identification of a large number of ancient and recent interspecific and inter gene pool introgression across the sequenced accessions. Surprising results included the consistent identification of a large introgression at chromosome Pv08 of the Andean varieties G19833, G24705, G4627 and G5686, which were thought to be completely Andean landraces. Introgression of haplotypes from $P$. acutifolius and $P$. coccineus was also identified within the genomes of improved varieties developed from interspecific crosses achieved by biotechnological tools such as embryo rescue (Waines et al., 1988). This includes the VAX lines, which are descendants of crosses between $P$. vulgaris and $P$. acutifolius to improve resistance to common bacterial blight. A consistent identification of an introgression on chromosome Pv08 suggests that this region holds the most important genes conferring the improved resistance in VAX lines. Similarly, introgressions of $P$. coccineus were identified at chromosomes Pv08, Pv10, and Pv11 of the advanced line ALB 213, which is known to be 
developed from a backcross experiment with a $P$. coccineus donor, looking for resistance to heat. Recently, 683 genotypes cultivated at different environmental conditions and subjected to different abiotic stresses were resequenced to perform association mapping with yield components, including seed size, flowering time and harvest maturity (Wu et al., 2020).

To elucidate the phylogenetic relationships among Phaseolus species, WGS was performed on 29 samples across 12 species (Rendón-Anaya et al., 2017). This study confirmed the hybridization event between $P$. coccineus and $P$. vulgaris giving rise to $P$. dumosus (Mina-Vargas et al., 2016). Within $P$. vulgaris, the phylogeny reconstruction clustered the wild Andean genotypes from the Amotape-Huancabamba depression in northern Peru apart from cultivars of both Andean and Mesoamerican origin, suggesting a further speciation event. Global interspecific and intraspecific introgression was assessed through the calculation of the D-statistic. This showed that intraspecific introgression was more frequent than interspecific introgression and that introgression is more frequent from domesticated to wild accessions than the opposite, probably due to selection against phenotypic characteristics conferred by wild alleles. Introgressions of genes from $P$. coccineus, $P$. dumosus and $P$. costaricencis into $P$. vulgaris are enriched for functional categories including cell wall organization and metabolism of polysaccharides, and are related to resistance to biotic stresses and to the adaptation of $P$. vulgaris to a wide range of environmental conditions.

Due to its cost effectiveness, Genotype-by-Sequencing (GBS) has been used as an alternative method to explore genetic variability in larger diversity panels, as well as controlled populations. Considering domesticated genotypes of common bean, Campa et al. (2018) performed GBS on 308 landraces from a Spanish diversity panel. A total of 3,099 SNPs were identified and genotyped to assess the genetic diversity of the population. Although the authors did not explicitly look for signatures of introgression, the pattern of admixture between Andean and Mesoamerican genetic backgrounds inferred from the structure analysis in 82 accessions suggested some level of introgression within landraces in this panel. These accessions correspond to the seed type termed "snap bean." Likewise, Valdisser et al. (2017) genotyped 188 samples, including 91 landraces from the Brazilian core collection and 97 breeding lines from different sources. A total of 6,286 SNPs were obtained in this work. Recent works considered larger panels to perform multisite GWAS and genomic prediction for different traits. Oladzad et al. (2019) generated GBS data of 807 common bean genotypes (469 Mesoamerican and 325 Andean) to perform multisite phenotype association for different traits in moderate subsets of about 120 accessions, following an approach termed Bean Abiotic Stress Evaluation (BASE). Significant associations were identified for yield, flowering time, the level of green color and tolerance to the Macrophomina phaseolina disease under heat stress. Likewise, MacQueen et al. (2020) presented the results obtained from genotyping of 327 accessions from the Cooperative Dry Bean Nursery (CDBN) which are cultivated in the United States and Canada. A total of 1.2 million SNPs were obtained to perform association with 21 different traits related to yield, grain quality and resistance to biotic stresses.
Significant associations were identified for 8 of the 21 traits. In Nay et al. (2019) GBS was performed on a panel of 316 lines from the International Center for Tropical Agriculture (CIAT) to identify associations with Angular Leaf Spot (ALS). Finally, Keller et al. (2020) generated GBS data on 481 elite Andean breeding lines from CIAT (called the VEF panel) to evaluate different models of genomic prediction for yield, flowering time and seed weight under drought conditions.

Regarding genotyping of wild common bean populations, Ariani et al. (2018) analyzed GBS data for 246 wild accessions from the major gene pools, including 77 accessions from the southern Andes and 12 accessions from the AmotapeHuancabamba depression (termed PhI for phaseolin I). Despite the lower number of samples, the PhI population showed higher diversity than the wild Andean population. A Bayesian analysis of different demographic models supported the hypothesis of a Mesoamerican origin of the species with a divergence of the $\mathrm{PhI}$ population about 373,000 years ago and a second divergence of the southern Andean population about 87,000 years ago. Regarding introgression, admixture signals suggested introgression between the Mesoamerican populations centered in central and northern Mexico, whereas some Mesoamerican accessions from Colombia showed introgression of Andean haplotypes. Cortés and Blair (2018) genotyped 86 wild accessions across the distribution range of $P$. vulgaris to assess genetic association with environmental variables, particularly with drought index. Divergence in population statistics such as nucleotide divergence and Tajima's D between associated and non-associated regions indicated divergent selection in wild common bean within these regions. This divergence is explained by the antagonistic role of early flowering time, which is advantageous in nondry conditions but is disadvantageous for tolerance to drought. These accessions were later reanalyzed to perform Genome-Wide Association with different climatic indexes related to heat stress, comparing different phenotype-genotype association models (López-Hernández and Cortés, 2019).

Regarding Lima bean, Chacón-Sánchez and Martínez-Castillo (2017) presented the results of a GBS experiment including 270 accessions (110 wild and 160 domesticated) spanning the major subpopulations of Lima bean, with the main goal of testing different scenarios for the dual domestication of this species. Using as reference the genome of the Andean common bean and after different filtering procedures, 4,992 SNPs were retained for downstream analysis. Although the sampling was more focused on the Mesoamerican populations, it was observed that a group of wild accessions from central Colombia diverged from the wild Andean population suggesting the presence of a new Andean gene pool in this region. Approximate Bayesian computation $(\mathrm{ABC})$ and diversity statistics suggested that a group of domesticated accessions seem to be derived by admixture between wild and domesticated gene pools. A recent study from our research groups generated GBS data for 214 additional Lima bean accessions (Garcia et al., 2021). This increased sampling confirmed the presence of the Colombian wild cluster, provided new information on the distribution of genetic variability in wild and domesticated accessions, and supplied detailed information about the presence of chromosomal segments in seven percent of 
the studied accessions that were likely the result of intraspecific gene flow. Furthermore, the study showed that cultivars of the Yucatán Peninsula were introduced from their area of domestication in central-western Mexico and interestingly, in this region wild-weedy-crop gene flow was not observed either from wild to domesticated, or vice versa.

Finally, Cortés et al. (2018) reanalyzed data of 130 Lima bean and 79 common bean accessions to study patterns of genetic differentiation between species, between gene pools within species and between wild and cultivated accessions. First, they validated that genomic islands produced by speciation are not necessarily related to divergence within species. Only one of the regions of large $\mathrm{F}_{\mathrm{ST}}$ between species on chromosome 11 colocalized with $\mathrm{F}_{\mathrm{ST}}$ outliers between gene pools and a second region at chromosome 3 colocated with outliers marking wild vs. cultivated differentiation. Then, they identified three genomic regions at chromosomes 1, 5 and 11 showing genetic differentiation between gene pools in at least two comparisons. Likewise, five regions of genetic differentiation between wild and cultivated accessions at chromosomes 2, 3, 8, 10 and 11 appeared in at least two comparisons. Possible explanations for the moderate amount of colocalization of these events across comparisons include the wide range of adaptations needed to colonize large regions with different environmental conditions and the complex genetic architecture of quantitative traits.

All these studies demonstrate that high throughput DNA sequencing is a very powerful tool to generate information of genomic variability both between and within species and consequently document events of gene flow at different evolutionary levels. Although a chromosome-level assembly is only available for two species within the Phaseolus genus, resequencing information from other species has been already useful to document hybridization events that resulted in new species such as $P$. dumosus (Rendón-Anaya et al., 2017). The current availability of long-read sequencing technologies will allow obtaining chromosome-level genome assemblies for the main species of the genus and even for the main gene pools within species. Comparative genomics on these assemblies will elucidate the major structural rearrangements shaping the evolutionary history of Phaseolus genomes, possibly revealing further hybridization events. In turn, both GBS and WGS on large panels have been useful to identify signals of introgression within species at the individual level, including both ancient gene flow and recent admixture events resulting from breeding efforts. As shown in common bean (Lobaton et al., 2018), identifying these introgression signals is important, not only to document the genomic footprint of breeding, but also to provide useful information to find genomic loci related to agronomically important traits such as resistance to biotic and abiotic stresses.

Regarding sequencing protocols, the cost effectiveness of GBS allows to assess information on populations of hundreds and even thousands of individuals, which increases the chances of identification of plants with unobserved patterns of admixture, potentially saving an important amount of breeding efforts. However, the relatively low density of variants queried by GBS protocols could potentially introduce biases in the introgression analysis and could not provide enough information to reliably detect important introgression events within the $1 \mathrm{Mbp}$ range. Moreover, GBS datasets produced by different enzyme selection techniques are usually not compatible to perform large-scale meta-analyses combining different studies. Considering that Phaseolus genomes are relatively small compared to other plant species, WGS of large populations is feasible, and it produces datasets with a nearly complete variant density, allowing identifying and defining boundaries for introgression events with increased precision. Moreover, sequencing efforts generated by different groups can be combined to achieve a more comprehensive use of the sequencing information through collaboration.

Availability of population scale WGS data will provide definite answers to important questions: (1) which are the genetic drivers of traits selected during the domestication process? (2) which genes experience convergent evolution along this process? and (3) which are the genetic drivers of the large capacity of adaptation observed in $P$. vulgaris and $P$. lunatus, including adaptive introgression? Answers to these questions can provide useful information to take decisions on conservation of biodiversity and to guide future breeding efforts.

\section{DISCUSSION AND PERSPECTIVES}

This work suggests the following points for discussion. First, it seems that natural selection results in several members of the tribe Phaseoleae [Glycine: Abe (2000); Phaseolus: present results, for five species; Vigna subgen. Ceratotropis: Tomooka et al. (2001); Vigna subgen. Vigna: Coulibaly et al. (2002)] having selfing with variable levels of outcrossing, as the mechanism to generate and keep genetic diversity within natural populations. In case of no insect activity and absence of the CMS determinant (Hervieu et al., 1993), a few seeds will be produced by selfing [resulting in low genetic diversity: Hamrick and Godt (1990)]. If there is abundant insect activity, for instance under high temperatures [which will increase the production of pollen: Halterlein et al. (1980)], outcrossing might be important, likely resulting in higher genetic variation. In populations with plants with the CMS determinant, several and different restorer genes (Hervieu et al., 1993) might be acting to set fertility back to normal through pollen-mediated gene flow. For species survival, this dual reproductive strategy seems to have been critical (Hamrick and Godt, 1996). Thus, for the conservation of the wild species in situ, it is of paramount importance to consider the natural pollinators as well.

Second, it is evident that more studies are needed on the reproductive biology of the genus Phaseolus, particularly in the field, since for most of the over eighty species both breeding systems and natural gene flows are still poorly documented. In the genus, so far, there is one known case of species arising from natural hybridization, that of $P$. dumosus (Mina-Vargas et al., 2016). The contrast in areas of occupancy between the ancestral form of the year-bean and the weedy form, although both preferentially allogamous (Delgado Salinas, 1988), strongly invites to investigate further the genetic background behind that expansion. In this regard, there seems to be no straight 
correlation between the breeding system and expansion, in view of the cases of $P$. acutifolius, $P$. coccineus, $P$. lunatus and $P$. vulgaris, all as wild forms. Interestingly, $P$. microcarpus (an inbreeder: Carl Friedrich Philipp von Martius described this species in 1829 on a plant producing pods in "warmen Hause" in Munich, Germany) has an expansion larger than the one of wild $P$. coccineus (an outbreeder) (Debouck et al., 2019).

Third, one should note that this dual reproductive system seems to be an ancestral trait that went through domestication largely unaffected. However, pre-Columbian farmers - legendary plant breeders - were aware that a generator of variability was at work [just as they noted it on maize: Wilkes (1977); MorenoLetelier et al. (2020)]. As seen in the Lima bean model (section 5 ), because of the presence of linamarin, farmers tolerate or eliminate, depending on the context, the variability resulting from the gene flow with sympatric wild forms. Similarly, in common bean (section 4), at least up to a recent past, a few farmers were still making selections in the hybrid swarms (Debouck et al., 1989c), likely following the example of former generations. Thus, thanks to gene flow, pre-Columbian farmers were able to select hundreds of different landraces and to expand the ranges of their bean crops, far away from the original domestication spot. A brilliant example of this is race 'Nueva Granada, originally from the central/southern Andes (Chacón et al., 2005; Bitocchi et al., 2013) and acquiring unique attributes in the northern Andes (Singh et al., 1991; Kwak et al., 2012), before a very successful expansion in eastern Africa (Wortmann et al., 1998). The presence of races in reported autogamous crops can only be explained by gene flow and differential selection pressures by farmers in their original environments. This could explain the nature of race 'Guatemala' as distinct from race 'Mesoamerica' (Beebe et al., 2000; Blair et al., 2012). But as they were aware that a mechanism generating variability was present (“mis ibes se vuelven amargo, Mister," a Mayan farmer told DGD in Cumpich, N Campeche of Mexico, in January 1979), farmers were also taking benefit of selfing, at least in three of the five cultigens, apart from taking their bean crops away from the wild relatives or weeding the latter out of the fields, depending on the context. Incidentally, while governments often drudge to implement farmers' rights, here there is an opportunity to recognize 'domesticators" rights.

Fourth, notwithstanding evidence has accumulated about the widespread occurrence of wild-weedy-crop complexes along the natural range of distribution of Phaseolus species, and also some evidence have been gathered about the variability generated in these complexes, the usefulness of this variability for crop improvement has been poorly studied. Here, we call the attention that this is a subject that needs to be addressed urgently given the high risk that face the continuity of these complexes as a consequence of changes in farmers' behavior, especially in consumption and ways of subsistence, and the lack of preservation of habitats where wild and weedy types can survive (Beebe et al., 1997). Weedy and landrace types could be readily evaluated for the presence of useful recombinants and this could be coupled with genomic analyses of these recombinants (including transcriptome and proteome analyses) for three main purposes: (1) to determine how effective these complexes have been in broadening the genetic base of landrace populations, (2) to detect regions of the genome that have been introgressed from wild populations and (3) to evaluate the adaptive value of these introgressions, as have been recently reviewed (Burgarella et al., 2019). One well-known example of genome-wide effects of introgression and evidence of adaptive introgression is the incorporation of alleles from a congeneric wild relative (Zea mays ssp. mexicana) into maize landraces introduced to the central highlands in Mexico (Hufford et al., 2013; Moreno-Letelier et al., 2020). So the question here is not only to evaluate how effective these complexes have been in generating variability, but also whether this variability has been of any value for farmers and whether it can be of any value for breeding programs.

In conclusion, with this review we have illustrated that in the genus Phaseolus interspecific and intraspecific (wild-weedy-crop) gene flow may generate useful recombinants that may contribute to increase the ecological fitness of wild species (for example, weedy $P$. dumosus) and cultigens. The opportunities to find these recombinants will be higher in geographical regions where contact has been longer and in this sense, future studies should focus on primary centers of diversity, especially in places where traditional agriculture is still practiced (as shown by the Mayan traditional agriculture for Lima bean). In these places, farmers are more willing to tolerate weedy types, which act as genetic bridges between wild and domestic populations. Understanding the evolutionary dynamics of the wild-weedy-crop complexes is of such great importance that it should be a requisite for developing conservation policy in the centers of domestication and diversity of crops. Nowadays, we count with the technology and analytical tools to detect genomic introgressions but beyond this we need to evaluate the agronomical value of the recombinants, taking into account farmers' knowledge. This will save years of breeding and thus will help us to give a quicker response to current and future challenges of crop production.

\section{AUTHOR CONTRIBUTIONS}

MC-S contributed the section four and coordinated the preparation of the manuscript. JM-C contributed the section five. DD contributed the sections one, two, and three. JD contributed the section six. All authors read and approved the final version of the manuscript.

\section{FUNDING}

MC-S received funding from Colciencias, Colombia, under project code 1101-658-42502. JM-C received funding from CONACYT-Mexico (project codes CB2007-82642 and CB2014240984). DD received grants from the International Board for Plant Genetic Resources, the World Conservation Union, the United States Department of Agriculture, the Bundesministerium für Wirtschaftliche Zusammenarbeit und Entwicklung of Germany, and the Global Crop Diversity Trust for the field work since 1978, which are deeply acknowledged. JD received Internal funding of Universidad de los Andes through the FAPA research fund. 


\section{ACKNOWLEDGMENTS}

The support of the International Center for Tropical Agriculture (CIAT), its donors and the agricultural research services of Mexico, Guatemala, El Salvador,

\section{REFERENCES}

Abe, J. (2000). “The genetic structure of natural populations of wild soybeans revealed by isozymes and RFLPs of mitochondrial DNAs: possible influence of seed dispersal, cross-pollination and demography," in Wild Legumes, ed. K. Oono (Tsukuba: National Institute of Agrobiological Resources), 143-158.

Aceituno, F. J., and Loaiza, N. (2014). Early and Middle Holocene evidence for plant use and cultivation in the Middle Cauca River Basin, Cordillera Central (Colombia). Quat. Sci. Rev. 86, 49-62. doi: 10.1016/j.quascirev.2013.12.013

Acosta Gallegos, J. A., Gepts, P., and Debouck, D. G. (1994). Observations on wild and weedy accessions of common beans in Oaxaca, Mexico. Annu. Rep. Bean Improv. Coop. 37, 137-138.

Adams, M. W. (1977). An estimation of homogeneity in crop plants, with special reference to genetic vulnerability in the dry bean, Phaseolus vulgaris $\mathrm{L}$. Euphytica 26, 665-679. doi: 10.1007/bf00021692

Allard, R. W., and Workman, P. L. (1963). Population studies in predominantly self-pollinated species. IV. Seasonal fluctuations in estimated values of genetic parameters in Lima bean populations. Evolution 17, 470-480. doi: 10.2307/ 2407097

Almeida, C. P., Paulino, J. F., Morais Carbonell, S. A., Chiorato, A. F., Song, Q., Di Vittori, V., et al. (2020). Genetic diversity, population structure, and Andean introgression in Brazilian common bean cultivars after half a century of genetic breeding. Genes 11:1298. doi: 10.3390/genes11111298

Andersson, M., and de Vicente, M. C. (2010). Gene flow between crops and their wild relatives. Evol. Appl. 3, 402-403. doi: 10.1111/j.1752-4571.2010.00138.x

Andueza-Noh, R. H., Camacho-Pérez, L., Martínez-Castillo, J., and May-Pat, F. (2016). Distribución geográfica de los parientes silvestres del acervo genético mesoamericano del frijol lima (Phaseolus lunatus L.) en México. Polibotánica 41, 101-113.

Angioi, S. A., Rau, D., Attene, G., Nanni, L., Bellucci, E., Logozzo, G., et al. (2010). Beans in Europe: origin and structure of the European landraces of Phaseolus vulgaris L. Theor. Appl. Genet. 121, 829-843. doi: 10.1007/s00122-010-1353-2

Araya Villalobos, R., González Ugalde, W. G., Camacho Chacón, F., Sánchez Trejos, P., and Debouck, D. G. (2001). Observations on the geographic distribution, ecology and conservation status of several Phaseolus bean species in Costa Rica. Genet. Resour. Crop Evol. 48, 221-232.

Ariani, A., Berny Mier, Y., Teran, J. C., and Gepts, P. (2018). Spatial and temporal scales of range expansion in wild Phaseolus vulgaris. Mol. Biol. Evol. 35, 119-131. doi: 10.1093/molbev/msx273

Arnaud, J. F., Viard, F., Delescluse, M., and Cuguen, J. (2003). Evidence for gene flow via seed dispersal from crop to wild relatives in Beta vulgaris (Chenopodiaceae): consequences for the release of genetically modified crop species with weedy lineages. Proc. Biol. Sci. 270, 1565-1571. doi: 10.1098/rspb. 2003.2407

Arroyo, M. T. K. (1981). "Breeding systems and pollination biology in Leguminosae," in Advances in Legume Systematics, eds R. M. Polhill and P. H. Raven (Kew: Royal Botanic Gardens), 723-769.

Baker, H. G., and Baker, I. (1983). "A brief historical review of the chemistry of floral nectar," in The Biology of Nectaries, eds B. Bentley and T. S. Elias (New York, NY: Columbia University Press), 126-152.

Ballesteros, G. A. (1999). Contribuciones al Conocimiento del Frijol Lima (Phaseolus lunatus L.) en América Tropical. Ph. D. dissertation. Montecillos: Colegio de Postgraduados, Montecillos.

Barrons, K. C. (1938). Natural crossing in beans at different degrees of isolation. J. Am. Soc. Hortic. Sci. 36, 637-640.

Baudoin, J. P., Barthelemy, J. P., and Ndungo, V. (1991). Variability of cyanide contents in the primary and secondary genepools of the lima bean, Phaseolus lunatus L. Plant Genet. Resour. Newsl. 85, 5-9.

Baudoin, J. P., Degreef, J., Hardy, O., Janart, F., and Zoro Bi, I. (1998). "Development of an in situ conservation strategy for wild Lima bean (Phaseolus
Costa Rica, Panama, Colombia, Ecuador, Peru, Bolivia, Chile, and Argentina since 1977 is fully acknowledged. Thanks are also due to Matilde M. Ortiz-García, Felix Dzul-Tejero, and Filogonio May-Pat for laboratory and field support.

lunatus L.) populations in the central valley of Costa Rica," in Reproduction Biology, eds S. J. Owens and P. J. Rudall (Kew: Royal Botanic Garden Press), 417-426.

Baudoin, J. P., Rocha, O., Degreef, J., Maquet, A., and Guarino, L. (2004). Ecogeography, Demography, Diversity and Conservation of Phaseolus lunatus L. in the Central Valley of Costa Rica. Rome: International Plant Genetic Resources Institute.

Becerra-Velásquez, V., Paredes, C. M., and Debouck, D. G. (2011). Genetic relationships of common bean (Phaseolus vulgaris L.) race Chile with wild Andean and Mesoamerican germplasm. Chil. J. Agric. Res. 71, 3-15. doi: 10. 4067/s0718-58392011000100001

Beebe, S., Rengifo, J., Gaitan, E., Duque, M. C., and Tohme, J. (2001). Diversity and origin of Andean landraces of common bean. Crop Sci. 41, 854-862. doi: 10.2135/cropsci2001.413854x

Beebe, S., Skroch, P. W., Tohme, J., Duque, M. C., Pedraza, F., and Nienhuis, J. (2000). Structure of genetic diversity among common bean landraces of Middle American origin based on correspondence analysis of RAPD. Crop Sci. 40, 264-273. doi: 10.2135/cropsci2000.401264x

Beebe, S., Toro Ch, O., González, A. V., Chacón, M. I., and Debouck, D. G. (1997) Wild-weed-crop complexes of common bean (Phaseolus vulgaris L., Fabaceae) in the Andes of Peru and Colombia, and their implications for conservation and breeding. Genet. Resour. Crop Evol. 44, 73-91.

Berrie, A. M. M. (1977). An Introduction to the Botany of the Major Crop Plants. London: Heyden \& Son Ltd.

Bitocchi, E., Bellucci, E., Giardini, A., Rau, D., Rodriguez, M., Biagetti, E., et al. (2013). Molecular analysis of the parallel domestication of the common bean (Phaseolus vulgaris) in Mesoamerica and the Andes. New Phytol. 197, 300-313. doi: 10.1111/j.1469-8137.2012.04377.x

Blair, M. W., Brondani, R. V. P., Díaz, L. M., and Del Peloso, M. J. (2013). Diversity and population structure of common bean from Brazil. Crop Sci. 53, 1983-1993. doi: 10.2135/cropsci2012.09.0516

Blair, M. W., Soler, A., and Cortés, A. J. (2012). Diversification and population structure in common beans (Phaseolus vulgaris L.). PLoS One 7:e49488. doi: 10.1371/journal.pone.0049488

Blanca, J., Cañizares, J., Cordero, L., Pascual, L., Diez, M. J., and Nuez, F. (2012). Variation revealed by SNP genotyping and morphology provides insight into the origin of the tomato. PLoS One 7:e48198. doi: 10.1371/journal.pone. 0048198

Bliss, F. A. (1980). “Common bean,” in Hybridization of Crop Plants, eds W. R. Fehr and H. H. Hadley (Madison, WI: American Society of Agronomy and Crop Science Society of America), 273-284.

Brücher, H. (1954). Argentinien, Urheimat unserer Bohnen. Umsch. Wiss. Tech. 54, 14-15.

Brunner, B. R., and Beaver, J. S. (1989). Estimation of outcrossing of the common bean in Puerto Rico. HortScience 24, 669-671.

Burgarella, C., Barnaud, A., Kane, N. A., Jankowski, F., Scarcelli, N., Billot, C., et al. (2019). Adaptive introgression: an untapped evolutionary mechanism for crop adaptation. Front. Plant Sci. 10:4. doi: 10.3389/fpls.2019. 00004

Burle, M. L., Fonseca, J. R., Kami, J. A., and Gepts, P. (2010). Microsatellite diversity and genetic structure among common bean (Phaseolus vulgaris L.) landraces in Brazil, a secondary center of diversity. Theor. Appl. Genet. 121, 801-813. doi: 10.1007/s00122-010-1350-5

Burquez, A., and Sarukhán, K. J. (1980). Biología de poblaciones silvestres y cultivadas de Phaseolus coccineus L.: I. Relaciones planta-polinizador. Bot. Sci. 39, 5-24. doi: 10.17129/botsci.1173

Campa, A., Murube, E., and Ferreira, J. J. (2018). Genetic diversity, population structure, and linkage disequilibrium in a Spanish common bean diversity panel revealed through genotyping-by-sequencing. Genes 9:518. doi: 10.3390/ genes 9110518 
Chacón, S. M. I., Pickersgill, B., and Debouck, D. G. (2005). Domestication patterns in common bean (Phaseolus vulgaris L.) and the origin of the Mesoamerican and Andean cultivated races. Theor. Appl. Genet. 110, 432-444. doi: 10.1007/ s00122-004-1842-2

Chacón-Sánchez, M. I., and Martínez-Castillo, J. (2017). Testing domestication scenarios of Lima bean (Phaseolus lunatus L.) in Mesoamerica: insights from genome-wide genetic markers. Front. Plant Sci. 8:1551. doi: 10.3389/fpls.2017. 01551

Chaves-Barrantes, N. F., Araya-Villalobos, R., and Debouck, D. G. (2014). Cruzamiento natural en frijol común en Costa Rica. Agron. Mesoam. 25, 23-33. doi: 10.15517/am.v25i1.14490

Chaves-Barrantes, N., Araya-Villalobos, R., and Debouck, D. G. (2009). Flujo de genes entre frijol común y silvestre en Costa Rica. Agron. Mesoam. 20, 237-244. doi: 10.15517/am.v20i2.4940

Cortés, A. J., and Blair, M. W. (2018). Genotyping by sequencing and genomeenvironment associations in wild common bean predict widespread divergent adaptation to drought. Front. Plant Sci. 9:128. doi: 10.3389/fpls.2018.00128

Cortés, A. J., Skeen, P., Blair, M. W., and Chacón-Sánchez, M. I. (2018). Does the genomic landscape of species divergence in Phaseolus beans coerce parallel signatures of adaptation and domestication? Front. Plant Sci. 9:1816. doi: 10. 3389/fpls.2018.01816

Coulibaly, S., Pasquet, R. S., Papa, R., and Gepts, P. (2002). AFLP analysis of the phenetic organization and genetic diversity of Vigna unguiculata L. Walp. reveals extensive gene flow between wild and domesticated types. Theor. Appl. Genet. 104, 358-366. doi: 10.1007/s001220100740

Crispín, M. A. (1960). Cruzamiento natural en fríjol. Agric. Téc. Méx. 11, 38-39.

Darwin, C. (1858). On the agency of bees on the fertilization of papilionaceous flowers and on the crossing of kidney beans. Ann. Mag. Nat. Hist. 2, 459-465. doi: 10.1080/00222935808697064

Darwin, C. (1859). On the Origin of Species by Means of Natural Selection, or the Preservation of Favoured Races in the Struggle for Life. London: John Murray.

Debouck, D. G. (1988). Recolección de Germoplasma de Phaseolus en Bolivia. Cali: Centro Internacional de Agricultura Tropical.

Debouck, D. G. (1990). Wild beans as a food resource in the Andes. Annu. Rep. Bean Improv. Coop. 33, 102-103.

Debouck, D. G. (1994). Germplasm Exploration for the Genera Capsicum and Phaseolus in South Central Bolivia. Cali: Centro Internacional de Agricultura Tropical.

Debouck, D. G. (1995). Germplasm Exploration for the Genera Manihot and Phaseolus in Western and Central Guatemala. Original Report. Cali: Centro Internacional de Agricultura Tropical.

Debouck, D. G. (2000). "Genetic resources of Phaseolus beans: patterns in time, space, and people," in La Judía en un Nuevo Marco de Calidad, 2nd Seminario de Judía de la Península Ibérica, eds M. A. Fueyo Olmo, A. J. González Fernández, J. J. Ferreira Fernández, and R. Giraldez Ceballos-Escalera (Villaviciosa: Asturgraf), 17-39.

Debouck, D. G. (2016). "Your beans of the last harvest and the possible adoption of bright ideas," in Ethnobotany of Mexico: Interactions of People and Plants in Mesoamerica, eds R. Lira, A. Casas, and J. Blancas (New York, NY: Springer), 367-387. doi: 10.1007/978-1-4614-6669-7_14

Debouck, D. G. (2017). "Domesticaciones americanas: cuando la recursividad humana con ayuda de algunas plantas hace maravillas contra el peso de la geografía y de la migración original," in Domesticación en el Continente Americano: Investigación para el Manejo Sustentable de Recursos Genéticos en el Nuevo Mundo, eds A. Casas, J. Torres-Guevara, and F. Parra (México: Universidad Nacional Autónoma de México), 135-149.

Debouck, D. G. (2019). Cahiers de phaséologie - section Paniculati Freytag [Online]. Cali: International Center for Tropical Agriculture, 455.

Debouck, D. G., and Smartt, J. (1995). "Beans, Phaseolus spp. (LeguminosaePapilionoideae)," in Evolution of Crop Plants, 2nd Edn, eds J. Smartt and N. W. Simmonds (London: Longman Scientific \& Technical), 287-294.

Debouck, D. G., Araya Villalobos, R., Ocampo Sánchez, R. A., and González Ugalde, W. G. (1989a). Collecting Phaseolus in Costa Rica. Plant Genet. Resour. Newsl. 78-79, 44-46.

Debouck, D. G., Castillo, R., and Tohme, J. (1989b). Observations on littleknown Phaseolus germplasm of Ecuador. Plant Genet. Resour. Newsl. 80, $15-21$.
Debouck, D. G., Chaves-Barrantes, N., and Araya-Villalobos, R. (2019). New records of Phaseolus microcarpus (Leguminosae: Phaseoleae) for Costa Rica. J. Bot. Res. Inst. Tex. 13, 209-215.

Debouck, D. G., Gamarra, M., Ortiz, A. V., and Tohme, J. (1989c). Presence of a Wild Weed-Crop Complex in Phaseolus vulgaris L. in Peru? Annu. Rep. Bean Improv. Coop. 32, 64-65.

Debouck, D. G., Liñan Jara, J. H., Campana Sierra, A., and De La Cruz Rojas, J. H. (1987). Observations on the domestication of Phaseolus lunatus L. Plant Genet. Resour. Newsl. 70, 26-32.

Debouck, D. G., Toro, O., Paredes, O. M., Johnson, W. C., and Gepts, P. (1993). Genetic diversity and ecological distribution of Phaseolus vulgaris (Fabaceae) in northwestern South America. Econ. Bot. 47, 408-423. doi: 10.1007/bf02907356

Degreef, J., Rocha, O. J., Vanderborght, T., and Baudoin, J. P. (2002). Soil seed bank and seed dormancy in wild populations of lima bean (Fabaceae): considerations for in situ and ex situ conservation. Am. J. Bot. 89, 1644-1650. doi: 10.3732/ajb. 89.10.1644

Delgado Salinas, A. (1988). "Variation, taxonomy, domestication and germplasm potentialities in Phaseolus coccineus," in Genetic resources of Phaseolus Beans, ed. P. Gepts (Holland: Kluwer Academic Publishers), 441-463. doi: 10.1007/ 978-94-009-2786-5_18

Delgado-Salinas, A. O. (1985). Systematics of the Genus Phaseolus (Leguminosae) in North and Central America. Ph.D. thesis. Austin, TX: University of TexasAustin.

Delgado-Salinas, A., Bibler, R., and Lavin, M. (2006). Phylogeny of the genus Phaseolus (leguminosae): a recent diversification in an ancient landscape. Syst. Bot. 31, 779-791. doi: 10.1600/036364406779695960

Delgado-Salinas, A., Bruneau, A., and Doyle, J. J. (1993). Chloroplast DNA Phylogenetic Studies in New World Phaseolinae (Leguminosae: Papilionoideae: Phaseoleae). Syst. Bot. 18, 6-17. doi: 10.2307/2419784

Delgado-Salinas, A., Thulin, M., Pasquet, R., Weeden, N., and Lavin, M. (2011). Vigna (Leguminosae) sensu lato: the names and identities of the American segregate genera. Am. J. Bot. 98, 1694-1715. doi: 10.3732/ajb.1100069

Desiderio, F., Bitocchi, E., Bellucci, E., Rau, D., Rodriguez, M., Attene, G., et al. (2013). Chloroplast microsatellite diversity in Phaseolus vulgaris. Front. Plant Sci. 3:312. doi: 10.3389/fpls.2012.00312

Dohle, S., Berny Mier, Y., Teran, J. C., Egan, A., Kisha, T., and Khoury, C. K. (2019). "Wild Beans (Phaseolus L.) of North America," in North American Crop Wild Relatives, eds S. Greene, K. Williams, C. Khoury, M. Kantar, and L. Marek (Cham: Springer), 99-127. doi: 10.1007/978-3-319-97121-6_4

Doutt, M. T. (1932). Anatomy of Phaseolus vulgaris L. var. Black Valentine. Technical Bulletin No. 128. (Michigan: Michigan State University), 1-31.

Drewes, S. I. (2008). Prospección y colecta de germoplasma silvestre de Phaseolus vulgaris en la zona central de Argentina. Plant Genet. Resour. Newsl. 155, 9-14.

Du, F. K., Peng, X. L., Liu, J. Q., Lascoux, M., Hu, F. S., and Petit, R. J. (2011). Direction and extent of organelle DNA introgression between two spruce species in the Qinghai-Tibetan Plateau. New Phytol. 192, 1024-1033. doi: 10.1111/j.1469-8137.2011.03853.x

Duputié, A., David, P., Debain, C., and Mckey, D. (2007). Natural hybridization between a clonally propagated crop, cassava (Manihot esculenta Crantz) and a wild relative in French Guiana. Mol. Ecol. 16, 3025-3038. doi: 10.1111/j.1365294x.2007.03340.x

Dzul-Tejero, F., Coello-Coello, J., and Martínez-Castillo, J. (2014). Wild to crop introgression and genetic diversity in Lima bean (Phaseolus lunatus L.) in traditional Mayan milpas from Mexico. Conserv. Genet. 15, 1315-1328. doi: 10.1007/s10592-014-0619-7

Ellstrand, N. C., Prentice, H. C., and Hancock, J. F. (1999). Gene flow and introgression from domesticated plants into their wild relatives. Annu. Rev. Ecol. Syst. 30, 539-563. doi: 10.1146/annurev.ecolsys.30.1.539

Escalante, A. M., Coello, G., Eguiarte, L. E., and Piñero, D. (1994). Genetic structure and mating systems in wild and cultivated populations of Phaseolus coccineus and P. vulgaris (Fabaceae). Am. J. Bot. 81, 1096-1103. doi: 10.2307/2445471

Esquivel, M., Castiñeiras, L., and Hammer, K. (1990). Origin, classification, variation and distribution of lima bean (Phaseolus lunatus L.) in the light of Cuban material. Euphytica 49, 89-97. doi: 10.1007/bf00027258

Evans, A. M. (1976). "Beans - Phaseolus spp. (Leguminosae - Papilionatae)," in Evolution of Crop Plants, ed. N. W. Simmonds (London: Longman), 168-172. 
Evans, A. M. (1980). "Structure, variation, evolution and classification in Phaseolus," in Advances in Legume Science, eds R. J. Summerfield and A. H. Bunting (Kew: Royal Botanic Gardens), 337-347.

Ferreira, J. J., Alvarez, E., Fueyo, M. A., Roca, A., and Giraldez, R. (2000). Determination of the outcrossing rate of Phaseolus vulgaris L. using seed protein markers. Euphytica 113, 259-263.

Free, J. B. (1966). The pollination of the beans Phaseolus multiflorus and Phaseolus vulgaris by honeybees. J. Apic. Res. 5, 87-91.

Free, J. B. (1968). The behaviour of bees visiting runner beans (Phaseolus multiflorus). J. Appl. Ecol. 5, 631-638. doi: 10.2307/2401637

Free, J. B., and Racey, P. A. (1968). The pollination of runner beans (Phaseolus multiflorus) in a glasshouse. J. Apic. Res. 7, 67-69. doi: 10.1080/00218839.1968. 11100191

Freyre, R., Ríos, R., Guzmán, L., Debouck, D. G., and Gepts, P. (1996). Ecogeographic distribution of Phaseolus spp. (Fabaceae) in Bolivia. Econ. Bot. 50, 195-215. doi: 10.1007/bf02861451

Freytag, G. F., and Debouck, D. G. (1996). Phaseolus costaricensis, a new wild species (Phaseolinae, Leguminosae) from Costa Rica and Panama, Central America. Novon 6, 157-163. doi: 10.2307/3391913

Freytag, G. F., and Debouck, D. G. (2002). Taxonomy, Distribution, and Ecology of the Genus Phaseolus (Leguminosae-papilionoideae) in North America, Mexico and Central America. Forth Worth, TX: Botanical Research Institute of Texas (BRIT).

Garcia, T., Duitama, J., Zullo, S. S., Gil, J., Ariani, A., Dohle, S., et al. (2021). Comprehensive genomic resources related to domestication and crop improvement traits in Lima bean. Nat. Commun. 12:702.

Gentry, H. S. (1969). Origin of the common bean, Phaseolus vulgaris. Econ. Bot. 23, 55-69. doi: 10.1007/bf02862972

Gepts, P., and Bliss, F. A. (1985). F1 hybrid weakness in the common bean. Differential geographic origin suggests two gene pools in cultivated bean germplasm. J. Hered. 76, 447-450. doi: 10.1093/oxfordjournals.jhered.a110142

Gepts, P., and Bliss, F. A. (1986). Phaseolin variability among wild and cultivated common bean (Phaseolus vulgaris) from Colombia. Econ. Bot. 40, 469-478. doi: $10.1007 /$ bf02859660

Gepts, P., and Bliss, F. A. (1988). Dissemination pathways of common bean (Phaseolus vulgaris, Fabaceae) deduced from phaseolin electrophoretic variability. II. Europe and Africa. Econ. Bot. 42, 86-104. doi: 10.1007/ bf02859038

Gepts, P., and Debouck, D. (1991). "Origin, domestication, and evolution of the common bean (Phaseolus vulgaris, L.)," in Common Beans: Research for Crop Improvement, eds A. Van Schoonhoven and O. Voysest (Wallingford: Commonwealth Agricultural Bureaux International), 7-53.

Gepts, P., and Papa, R. (2003). Possible effects of (trans)gene flow from crops on the genetic diversity from landraces and wild relatives. Environ. Biosaf. Res. 2, 89-103. doi: 10.1051/ebr:2003009

Gepts, P., González, A., Papa, R., Acosta, J., Wong, A., and Delgado Salinas, A. (2000). Outcrossing in Mexican wild and domesticated populations of common bean. Annu. Rep. Bean Improv. Coop. 43, 25-26.

Gepts, P., Kmiecik, K., Pereira, P., and Bliss, F. A. (1988). Dissemination pathways of common bean (Phaseolus vulgaris, Fabaceae) deduced from phaseolin electrophoretic variability. I. The Americas. Econ. Bot. 42, 73-85. doi: 10.1007/ bf02859036

Gioia, T., Logozzo, G., Attene, G., Bellucci, E., Benedettelli, S., Negri, V., et al. (2013). Evidence for introduction bottleneck and extensive inter-gene pool (Mesoamerica $\mathrm{x}$ Andes) hybridization in the European common bean (Phaseolus vulgaris L.) germplasm. PLoS One 8:e75974. doi: 10.1371/journal. pone. 0075974

Gioia, T., Logozzo, G., Marzario, S., Spagnoletti Zeuli, P., and Gepts, P. (2019). Evolution of SSR diversity from wild types to U.S. advanced cultivars in the Andean and Mesoamerican domestications of common bean (Phaseolus vulgaris). PLoS One 14:e0211342. doi: 10.1371/journal.pone.0211342

González Torres, R. I., Araya Villalobos, R., Gaitán Solís, E., and Debouck, D. G. (2004). Wild common bean in the Central Valley of Costa Rica: ecological distribution and molecular characterization. Agron. Mesoam. 15, 145-153.

González, A., Wong, A., Delgado-Salinas, A., Papa, R., and Gepts, P. (2005). Assessment of inter simple sequence repeat markers to differentiate sympatric wild and domesticated populations of common bean. Crop Sci. 45, 606-615. doi: $10.2135 /$ cropsci2005.0606
Guerra-García, A., Suárez-Atilano, M., Mastretta-Yanes, A., Delgado-Salinas, A., and Piñero, D. (2017). Domestication genomics of the open-pollinated scarlet runner bean (Phaseolus coccineus L.). Front. Plant Sci. 8:1891. doi: 10.3389/fpls. 2017.01891

Halterlein, A. J., Clayberg, C. D., and Teare, I. D. (1980). Influence of high temperature on pollen grain viability and pollen tube growth in the styles of Phaseolus vulgaris L. J. Am. Soc. Hortic. Sci. 105, 12-14.

Hamrick, J. L., and Godt, M. J. W. (1990). “Allozyme diversity in plant species," in Plant Population Genetics, Breeding, and Genetic Resources, eds A. H. D. Brown, M. T. Clegg, A. L. Kahler, and B. S. Weir (Sunderland, MA: Sinauer Associates, Inc), 43-63.

Hamrick, J. L., and Godt, M. J. W. (1996). "Conservation genetics of endemic plant species," in Conservation Genetics: Case Histories from Nature, eds J. C. Avise and J. L. Hamrick (New York, NY: Chapman \& Hall), 281-304. doi: 10.1007/978-1-4757-2504-9_9

Hardy, O., Dubois, S., Zoro Bi, I., and Baudoin, J. P. (1997). Gene dispersal and its consequences on the genetic structure of wild populations of lima bean (Phaseolus lunatus) in Costa Rica. Plant Genet. Resour. Newsl. 109, 1-6. doi: 10.3733/hilg.v15n01p001

Harlan, J. R. (1995). The Living Fields: Our Agricultural Heritage. Cambridge: Cambridge University Press.

Haygood, R., Ives, A. R., and Andow, D. A. (2003). Consequences of recurrent gene flow from crops to wild relatives. Proc. Biol. Sci. 270, 1879-1886. doi: $10.1098 /$ rspb.2003.2426

Hedström, I., and Thulin, M. (1986). Pollination by a hugging mechanism in Vigna vexillata (Leguminosae-Papilionoideae). Plant Syst. Evol. 154, 275-283. doi: 10.1007/bf00990129

Heiser, C. B. (1973). Introgression re-examined. Bot. Rev. 39, 347-366. doi: 10. 1007/bf02859160

Henslow, G. (1878). The fertilization of the scarlet runner by humble-bees. Gard. Chron. 10:561.

Hernández-Verdugo, S., Luna-Reyes, R., and Oyama, K. (2001). Genetic structure and differentiation of wild and domesticated populations of Capsicum annuum (Solanaceae) from Mexico. Plant System. Evol. 226, 129-142. doi: 10.1007/ s006060170061

Hervieu, F., Bannerot, H., and Pelletier, G. (1994). A unique cytoplasmic male sterility (CMS) determinant is present in three Phaseolus species characterized by different mitochondrial genomes. Theor. Appl. Genet. 88, 314-320. doi: $10.1007 /$ bf00223638

Hervieu, F., Charbonnier, L., Bannerot, H., and Pelletier, G. (1993). The cytoplasmic male-sterility (CMS) determinant of common bean is widespread in Phaseolus coccineus L. and Phaseolus vulgaris L. Curr. Genet. 24, 149-155. doi: $10.1007 /$ bf00324679

Hoc, P. S., Espert, S. M., Drewes, S. I., and Burghardt, A. D. (2006). Hybridization between wild and domesticated types of Phaseolus vulgaris L. (fabaceae) in Argentina. Genet. Resour. Crop Evol. 53, 331-337. doi: 10.1007/s10722-0041231-3

Hufford, M. B., Lubinksy, P., Pyhäjärvi, T., Devengenzo, M. T., Ellstrand, N. C., and Ross-Ibarra, J. (2013). The genomic signature of crop-wild introgression in maize. PLoS Genet. 9:e1003477. doi: 10.1371/journal.pgen.1003477

Hunter, J., Dickson, M., Boettger, M., and Cigna, J. A. (1982). Evaluation of plant introductions of Phaseolus spp. for resistance to white mold. Plant Dis. 66, 320-322. doi: 10.1094/pd-66-320

Ibarra-Pérez, F. J., Barnhart, D., Ehdaie, B., Knio, K. M., and Waines, J. G. (1999). Effects of insect tripping on seed yield of common bean. Crop Sci. 39, 428-433. doi: 10.2135/cropsci1999.0011183x0039000200022x

Ibarra-Pérez, F. J., Ehdaie, B., and Waines, J. G. (1997). Estimation of outcrossing rates in common bean. Crop Sci. 37, 60-65. doi: 10.2135/cropsci1997. 0011183x003700010009x

Ibarra-Pérez, F. J., Ehdaie, B., and Waines, J. G. (2000). Re-thinking the population structure of common bean. Annu. Rep. Bean Improv. Coop. 43, 23-24.

Ibarra-Pérez, F. J., Ellstrand, N. C., and Waines, J. G. (1996). Multiple paternity in common bean (Phaseolus vulgaris L, Fabaceae). Am. J. Bot. 83, 749-758. doi: $10.2307 / 2445852$

Ibrahim, A. M., and Coyne, D. P. (1975). Genetics of stigma shape, cotyledon position, and flower color in reciprocal crosses between Phaseolus vulgaris $\mathrm{L}$. and Phaseolus coccineus (Lam.) and implications in breeding. J. Am. Soc. Hortic. Sci. $100,622-626$. 
Inouye, D. W. (1983). “The ecology of nectar robbing”, in The Biology of Nectaries, eds B. Bentley and T. S. Elias (New York, NY: Columbia University Press), $153-173$.

Ishikawa, R., Yamanaka, S., Fukuta, Y., Chitrakon, S., Bounphanousay, C., Kanyavong, K., et al. (2006). Genetic erosion from modern varieties into traditional upland rice cultivars (Oryza sativa L.) in northern Thailand. Genet. Resour. Crop Evol. 53, 245-252. doi: 10.1007/s10722-004-6132-y

Islam, F. M. A., Beebe, S., Muñoz, M., Tohme, J., Redden, R. J., and Basford, K. E. (2004). Using molecular markers to assess the effect of introgression on quantitative attributes of common bean in the Andean gene pool. Theor. Appl. Genet. 108, 243-252. doi: 10.1007/s00122-003-1437-3

Kaplan, L. (1965). Archaeology and domestication in American Phaseolus (beans). Econ. Bot. 19, 358-368. doi: 10.1007/bf02904806

Kaplan, L., and Kaplan, L. N. (1992). "Beans of the Americas," in Chillies to Chocolate - Food the Americas Gave the world, eds N. Foster and L. S. Cordell (Tucson, AZ: The University of Arizona Press), 61-79.

Keller, B., Ariza-Suarez, D., De La Hoz, J., Aparicio, J. S., Portilla-Benavides, A. E., Buendia, H. F., et al. (2020). Genomic prediction of agronomic traits in common bean (Phaseolus vulgaris L.) under environmental stress. Front. Plant Sci. 11:1001. doi: 10.3389/fpls.2020.01001

Kendall, D. A., and Smith, B. D. (1976). The pollinating efficiency of honeybee and bumblebee visits to flowers of the runner bean Phaseolus coccineus L. J. Appl. Ecol. 13, 749-752. doi: 10.2307/2402252

Khairallah, M. M., Adams, M. W., and Sears, B. B. (1990). Mitochondrial DNA polymorphisms of Malawian bean lines: further evidence for two major gene pools. Theor. Appl. Genet. 80, 753-761. doi: 10.1007/bf00224188

Koinange, E. M. K., and Gepts, P. (1992). Hybrid weakness in wild Phaseolus vulgaris L. J. Hered. 83, 135-139. doi: 10.1093/oxfordjournals.jhered.a111173

Kwak, M., and Gepts, P. (2009). Structure of genetic diversity in the two major gene pools of common bean (Phaseolus vulgaris L., Fabaceae). Theor. Appl. Genet. 118, 979-992. doi: 10.1007/s00122-008-0955-4

Kwak, M., Kami, J. A., and Gepts, P. (2009). The putative Mesoamerican domestication center of Phaseolus vulgaris is located in the Lerma-Santiago basin of Mexico. Crop Sci. 49, 554-563. doi: 10.2135/cropsci2008.07.0421

Kwak, M., Toro, O., Debouck, D. G., and Gepts, P. (2012). Multiple origins of the determinate growth habit in domesticated common bean (Phaseolus vulgaris). Ann. Bot. 110, 1573-1580. doi: 10.1093/aob/mcs207

Lackey, J. A. (1983). A review of generic concepts in American Phaseolinae (Fabaceae, Faboideae). Iselya 2, 21-63.

Ladizinsky, G. (1998). Plant Evolution Under Domestication. Dordrecht: Kluwer Academic Publishers. doi: 10.1007/978-94-011-4429-2

Lavin, M., and Delgado-Salinas, A. (1990). Pollen brush of Papilionoideae (Leguminosae): morphological variation and systematic utility. Am. J. Bot. 77, 1294-1312. doi: 10.1002/j.1537-2197.1990.tb11381.x

Lioi, L., and Hammer, K. (1989). A wild race of Phaseolus vulgaris L. as a new source of phaseolin variation. Kulturpflanzen 37, 129-132. doi: 10.1007/bf01984609

Lobaton, J. D., Miller, T., Gil, J., Ariza, D., De La Hoz, J. F., Soler, A., et al. (2018). Resequencing of common bean identifies regions of inter-gene pool introgression and provides comprehensive resources for molecular breeding. Plant Genome 11:170068. doi: 10.3835/plantgenome2017.08.0068

López-Hernández, F., and Cortés, A. J. (2019). Last-generation genomeenvironment associations reveal the genetic basis of heat tolerance in common bean (Phaseolus vulgaris L.). Front. Genet. 10:954. doi: 10.3389/fgene.2019. 00954

Lord, E. M., and Webster, B. D. (1979). The stigmatic exudate of Phaseolus vulgaris L. Bot. Gaz. 140, 266-271. doi: 10.1086/337084

Mackenzie, S. A. (1991). Identification of a sterility-inducing cytoplasm in a fertile accession line of Phaseolus vulgaris L. Genetics 127, 411-416. doi: 10.1093/ genetics/127.2.411

Mackie, W. W., and Smith, F. L. (1935). Evidence of field hybridization in beans. Agron. J. 27, 903909.

MacQueen, A. H., White, J. W., Lee, R., Osorno, J. M., Schmutz, J., Miklas, P. N., et al. (2020). Genetic associations in four decades of multienvironment trials reveal agronomic trait evolution in common bean. Genetics 215, 267-284. doi: 10.1534/genetics.120.303038

Mahuku, G. S., Jara, C. E., Cajiao, C., and Beebe, S. (2002). Sources of resistance to Colletotrichum lindemuthianum in the secondary gene pool of Phaseolus vulgaris and in crosses of primary and secondary gene pools. Plant Dis. 86, 1383-1387. doi: 10.1094/pdis.2002.86.12.1383

Mamidi, S., Rossi, M., Annam, D., Moghaddam, S., Lee, R., Papa, R., et al. (2011). Investigation of the domestication of common bean (Phaseolus vulgaris) using multilocus sequence data. Funct. Plant Biol. 38, 953-967. doi: 10.1071/fp11124

Mandel, J. R., Ramsey, A. J., Iorizzo, M., and Simon, P. W. (2016). Patterns of gene flow between crop and wild carrot, Daucus carota (Apiaceae) in the United States. PLoS One 11:e0161971. doi: 10.1371/journal.pone.0161971

Mapes, C., and Basurto, F. (2016). "Biodiversity and edible plants of Mexico," in Ethnobotany of Mexico: Interactions of People and Plants in Mesoamerica, eds R. Lira, A. Casas, and J. Blancas (New York, NY: Springer), 83-131. doi: 10.1007/978-1-4614-6669-7_5

Martínez-Castillo, J., Colunga-Garcíamarín, P., and Zizumbo-Villarreal, D. (2008). Genetic erosion and in situ conservation of Lima bean (Phaseolus lunatus L.) landraces in its Mesoamerican diversity center. Genet. Resour. Crop Evol. 55, 1065-1077. doi: 10.1007/s10722-008-9314-1

Martínez-Castillo, J., Zizumbo-Villarreal, D., Gepts, P., and Colunga-Garcíamarín, P. (2007). Gene flow and genetic structure in the wild-weedy-domesticated complex of Phaseolus lunatus L. In its Mesoamerican center of domestication and diversity. Crop Sci. 47, 58-66. doi: 10.2135/cropsci2006.04.0241

Martínez-Castillo, J., Zizumbo-Villarreal, D., Gepts, P., Delgado-Valerio, P., and Colunga-Garcíamarín, P. (2006). Structure and genetic diversity of wild populations of Lima bean (Phaseolus lunatus L.) from the Yucatán Peninsula. Mexico. Crop Sci. 46, 1071-1080. doi: 10.2135/cropsci2005.05-0081

Martínez-Castillo, J., Zizumbo-Villarreal, D., Perales-Rivera, H., and ColungaGarcíamarin, P. (2004). Intraspecific diversity and morpho-phenological variation in Phaseolus lunatus L. from the Yucatán Peninsula, Mexico. Econ. Bot. 58, 354-380. doi: 10.1663/0013-0001(2004)058[0354:idamvi]2.0.co;2

Mazariegos, H. L. A. (2000). Hummingbirds of Colombia. Cali: Imprelibros S.A.

McCauley, D. E. (1994). Contrasting the distribution of chloroplast DNA and allozyme polymorphism among local populations of Silene alba: implications for studies of gene flow in plants. Proc. Natl. Acad. Sci. U.S.A. 91, 8127-8131. doi: 10.1073/pnas.91.17.8127

Mina-Vargas, A. M., Mckeown, P. C., Flanagan, N. S., Debouck, D. G., Kilian, A., Hodkinson, T. R., et al. (2016). Origin of year-long bean (Phaseolus dumosus Macfady, Fabaceae) from reticulated hybridization events between multiple Phaseolus species. Ann. Bot. 118, 957-969. doi: 10.1093/aob/mcw138

Miranda-Colín, S. (1971). Cruzamiento natural en frijol. Agric. Téc. Méx. 3, 48-52. Molosiwa, O., Kgokong, S., Makwala, B., Gwafila, C., and Ramokapane, M. (2014). Genetic diversity in Tepary bean (Phaseolus acutifolius) landraces grown in Botswana. J. Plant Breed. Crop Sci. 6, 194-199. doi: 10.5897/jpbcs2014.0458

Montes-Hernandez, S., and Eguiarte, L. E. (2002). Genetic structure and indirect estimates of gene flow in three taxa of Cucurbita (Cucurbitaceae) in western Mexico. Am. J. Bot. 89, 1156-1163. doi: 10.3732/ajb.89.7.1156

Moreno-Letelier, A., Aguirre-Liguori, J. A., Piñero, D., Vázquez-Lobo, A., and Eguiarte, L. E. (2020). The relevance of gene flow with wild relatives in understanding the domestication process. R. Soc. Open Sci. 7:191545. doi: 10.1098/rsos.191545

Motta-Aldana, J. R., Serrano-Serrano, M. L., Hernández-Torres, J., CastilloVillamizar, G., Debouck, D. G., and Chacóns, M. I. (2010). Multiple origins of Lima bean landraces in the Americas: evidence from chloroplast and nuclear DNA polymorphisms. Crop Sci. 50, 1773-1787. doi: 10.2135/cropsci2009.12. 0706

Muñoz, L. C., Duque, M. C., Debouck, D. G., and Blair, M. W. (2006). Taxonomy of tepary bean and wild relatives as determined by amplified fragment length polymorphism (AFLP) markers. Crop Sci. 46, 1744-1754. doi: 10.2135/ cropsci2005-12-0475

Mutschler, M. A., and Bliss, F. A. (1980). Genic male sterility in the common bean (Phaseolus vulgaris L.). J. Am. Soc. Hortic. Sci. 105, 202-205.

Nay, M. M., Mukankusi, C. M., Studer, B., and Raatz, B. (2019). Haplotypes at the Phg-2 locus are determining pathotype-specificity of angular leaf spot resistance in common bean. Front. Plant Sci. 10:1126. doi: 10.3389/fpls.2019.01126

Okonkwo, C. A., and Clayberg, C. D. (1984). The incidence of outcrossing as related to distance in Phaseolus coccineus L. Annu. Rep. Bean Improv. Coop. 27, 157-158.

Oladzad, A., Porch, T., Rosas, J. C., Moghaddam, S. M., Beaver, J., Beebe, S. E., et al. (2019). Single and multi-trait GWAS identify genetic factors associated 
with production traits in common bean under abiotic stress environments. G3 9, 1881-1892.

Opler, P. A. (1983). "Nectar production in a tropical ecosystem," in The Biology of Nectaries, eds B. Bentley and T. S. Elias (New York, NY: Columbia University Press), 30-79.

Papa, R., Acosta, J., Delgado-Salinas, A., and Gepts, P. (2005). A genome-wide analysis of differentiation between wild and domesticated Phaseolus vulgaris from Mesoamerica. Theor. Appl. Genet. 111, 1147-1158. doi: 10.1007/s00122005-0045-9

Papa, R., and Gepts, P. (2003). Asymmetry of gene flow and differential geographical structure of molecular diversity in wild and domesticated common bean (Phaseolus vulgaris L.) from Mesoamerica. Theor. Appl. Genet. 106, 239-250. doi: 10.1007/s00122-002-1085-Z

Paredes, O. M., and Gepts, P. (1995). Extensive introgression of Middle American germplasm into Chilean common bean cultivars. Genet. Resour. Crop Evol. 42, 29-41. doi: 10.1007/bf02310681

Payró de la Cruz, E., Gepts, P., Garciamarín, P. C., and Villareal, D. Z. (2005). Spatial distribution of genetic diversity in wild populations of Phaseolus vulgaris L. from Guanajuato and Michoacán, México. Genet. Resour. Crop Evol. 52, 589-599. doi: 10.1007/s10722-004-6125-x

Penha, J. S., Lopes, A. C. A., Gomes, R. L. F., Pinheiro, J. B., Assunção Filho, J. R., Silvestre, E. A., et al. (2017). Estimation of natural outcrossing rate and genetic diversity in Lima bean (Phaseolus lunatus L. var. lunatus) from Brazil using SSR markers: implications for conservation and breeding. Genet. Resour. Crop Evol. 64, 1355-1364. doi: 10.1007/s10722-016-0441-9

Pernès, J., Combes, D., and Leblanc, J. M. (1984). "Le mil," in Gestion des RESSOURCES génétiques des Plantes, ed. J. Pernès (Paris: Agence de Coopération Culturelle et Technique), 157-197.

Pickersgill, B. (1998). "Crop introductions and the development of secondary areas of diversity," in Plants for Food and Medicine, eds H. D. V. Prendergast, N. L. Etkin, D. R. Harris, and P. J. Houghton (Kew: Royal Botanic Gardens), 93-105.

Porch, G. T., Beaver, S. J., Debouck, G. D., Jackson, A. S., Kelly, D. J., and Dempewolf, H. (2013). Use of wild relatives and closely related species to adapt common bean to climate change. Agronomy 3, 433-461. doi: 10.3390/ agronomy3020433

Proctor, M., Yeo, P., and Lack, A. (1996). The Natural History of Pollination. Portland, OR: Timber Press.

Rabinowitz, D., Linder, C. R., Ortega, R., Begazo, D., Murguia, H., Douches, D. S., et al. (1990). High levels of interspecific hybridization between Solanum sparsipilum and S. stenotomum in experimental plots in the Andes. Am. Potato J. 67, 73-81. doi: 10.1007/bf02990957

Raggi, L., Tiranti, B., and Negri, V. (2013). Italian common bean landraces: diversity and population structure. Genet. Resour. Crop Evol. 60, 1515-1530. doi: 10.1007/s10722-012-9939-y

Ramírez-Delgadillo, R., and Delgado-Salinas, A. (1999). A new species of Phaseolus (Fabaceae) from west-central Mexico. SIDA 18, 637-646.

Regina-Royer, M., Gonçalves-Vidigal, M. C., Scapim, C. A., Vidigal-Filho, P. S., and Miglioranza, E. (2000). Natural outcrossing rates of bean cultivars (Phaseolus vulgaris L.). Annu. Rep. Bean Improv. Coop. 43, 194-195.

Rendón-Anaya, M., Montero-Vargas, J. M., Saburido-Álvarez, S., Vlasova, A., Capella-Gutierrez, S., Ordaz-Ortiz, J. J., et al. (2017). Genomic history of the origin and domestication of common bean unveils its closest sister species. Genome Biol. 18:60.

Rodiño, A. P., Santalla, M., González, A. M., De Ron, A. M., and Singh, S. P. (2006). Novel genetic variation in common bean from the Iberian Peninsula. Crop Sci. 46, 2540-2546. doi: 10.2135/cropsci2006.02.0104

Roullier, C., Duputié, A., Wennekes, P., Benoit, L., Fernández Bringas, V. M., Rossel, G., et al. (2013). Disentangling the origins of cultivated sweet potato (Ipomoea batatas (L.) Lam.). PLoS One 8:e62707. doi: 10.1371/journal.pone. 0062707

Rutger, J. N., and Beckham, L. S. (1970). Natural hybridization of Phaseolus vulgaris L. x Phaseolus coccineus L. J. Am. Soc. Hortic. Sci. 95, 659-661.

Santalla, M., Rodiño, A., and De Ron, A. (2002). Allozyme evidence supporting southwestern Europe as a secondary center of genetic diversity for the common bean. Theor. Appl. Genet. 104, 934-944. doi: 10.1007/s00122-001-0844-6

Schmit, V., and Baudoin, J. P. (1987). Multiplication et évaluation de Phaseolus coccineus L. et Phaseolus polyanthus Greenm., deux espèces intéressantes pour l'amélioration de la productivité des légumineuses vivrières. Bull. Rech. Agron. Gembloux 22, 235-253.

Schmit, V., and Debouck, D. G. (1991). Observations on the origin of Phaseolus polyanthus Greenman. Econ. Bot. 45, 345-364. doi: 10.1007/bf02887077

Schmutz, J., Mcclean, P. E., Mamidi, S., Wu, G. A., Cannon, S. B., Grimwood, J., et al. (2014). A reference genome for common bean and genome-wide analysis of dual domestications. Nat. Genet. 46, 707-713.

Schrire, B. D. (2005). "Tribe Phaseoleae," in Legumes of the World, eds G. Lewis, B. Schrire, B. Mackinder, and M. Lock (Kew: Royal Botanic Gardens), 392-431.

Sicard, D., Nanni, L., Porfiri, O., Bulfon, D., and Papa, R. (2005). Genetic diversity of Phaseolus vulgaris L. and P. coccineus L. landraces in central Italy. Plant Breed. 124, 464-472. doi: 10.1111/j.1439-0523.2005.01137.x

Silveira, E. P., Ferreira-Antunes, I., and Pauli, C. G. (2001). Effect of geographical orientation and isolation distance on outcrossing of common bean (Phaseolus vulgaris L.). Annu. Rep. Bean Improv. Coop. 44, 23-24.

Singh, S. P., and Gutiérrez, J. A. (1984). Geographical distribution of the DL1 and DL2 genes causing hybrid dwarfism in Phaseolus vulgaris L., their association with seed size, and their significance to breeding. Euphytica 33, 337-345. doi: $10.1007 /$ bf00021130

Singh, S. P., Gepts, P., and Debouck, D. G. (1991). Races of common bean (Phaseolus vulgaris, Fabaceae). Econ. Bot. 45, 379-396. doi: 10.1007/bf02887079

Song, Q., Jia, G., Hyten, D. L., Jenkins, J., Hwang, E.-Y., Schroeder, S. G., et al. (2015). SNP assay development for linkage map construction, anchoring wholegenome sequence, and other genetic and genomic applications in common bean. G3 5, 2285-2290. doi: 10.1534/g3.115.020594

Sonnante, G., Stockton, T., Nodari, R. O., Becerra Velásquez, V. L., and Gepts, P. (1994). Evolution of genetic diversity during the domestication of common bean (Phaseolus vulgaris L.). Theor. Appl. Genet. 89, 629-635.

Sousa-Peña, M., Wong-León, A., and Delgado-Salinas, A. (1996). "Pollination dynamics and evolution in the Phaseolus coccineus L. complex," in Advances in Legume Systematic. 8. Legumes of Economic Importance, eds B. Pickersiill and J. M. Lock (Kew: Royal Botanic Garden), 75-81.

Spataro, G., Tiranti, B., Arcaleni, P., Bellucci, E., Attene, G., Papa, R., et al. (2011). Genetic diversity and structure of a worldwide collection of Phaseolus coccineus L. Theor. Appl. Genet. 122, 1281-1291.

Stoetzer, H. A. I. (1984). Natural cross-pollination in bean in Ethiopia. Annu. Rep. Bean Improv. Coop. 27, 99-100.

Tohme, J., Toro, O., Vargas, J., and Debouck, D. G. (1995). Variability in Andean Nuña common beans (Phaseolus vulgaris, Fabaceae). Econ. Bot. 49, 78-95.

Tomooka, N., Vaughan, D., Xu, R.-Q., Kashiwaba, K., and Kaga, A. (2001). Japanese native Vigna genetic resources. Jpn. Agric. Res. Q. 35, 1-9.

Triana, B., Iwanaga, M., Rubiano, H., and Andrade, M. (1993). A study of allogamy in wild Phaseolus vulgaris. Annu. Rep. Bean Improv. Coop. 36, 20-21.

Ulloa Ulloa, C., Acevedo-Rodríguez, P., Beck, S., Belgrano, M. J., Bernal, R., Berry, P. E., et al. (2018). Vascular Plants of the Americas VPA Website. Available online at: http://www.tropicos.org/Project/VPA (accessed March 27, 2020).

Valdisser, P. A. M. R., Pereira, W. J., Almeida Filho, J. E., Müller, B. S. F., Coelho, G. R. C., De Menezes, I. P. P., et al. (2017). In-depth genome characterization of a Brazilian common bean core collection using DArTseq high-density SNP genotyping. BMC Genomics 18:423. doi: 10.1186/s12864-017-3805-4

Van Raamsdonk, L. W. D., and Van Der Maesen, L. J. G. (1996). Crop-weed complexes: the complex relationship between crop plants and their wild relatives. Acta Bot. Neerl. 45, 135-155.

van Rheenen, H. A., Muigai, S. G. S., and Kitivo, D. K. (1979). Male sterility in beans (Phaseolus vulgaris L.). Euphytica 28, 761-763.

Vlasova, A., Capella-Gutiérrez, S., Rendón-Anaya, M., Hernández-Oñate, M., Minoche, A. E., Erb, I., et al. (2016). Genome and transcriptome analysis of the Mesoamerican common bean and the role of gene duplications in establishing tissue and temporal specialization of genes. Genome Biol. 17:32.

Waines, J. G., and Barnhart, D. R. (2001). Low outcrossing rate in tepary bean and possible transfer of the self-pollination system to common and Lima bean. Annu. Rep. Bean Improv. Coop. 44, 25-26.

Waines, J. G., Manshardt, R. M., and Wells, W. C. (1988). "Interspecific hybridization between Phaseolus vulgaris and P. acutifolius," in Genetic Resources of Phaseolus Beans, ed. P. Gepts (Dordrecht: Kluwer Academic Publishers), 485-502. 
Warburton, M. L., Wilkes, G., Taba, S., Charcosset, A., Mir, C., Dumas, F., et al. (2011). Gene flow among different teosinte taxa and into the domesticated maize gene pool. Genet. Resour. Crop Evol. 58, 1243-1261.

Watling, J., Shock, M. P., Mongeló, G. Z., Almeida, F. O., Kater, T., De Oliveira, P. E., et al. (2018). Direct archaeological evidence for Southwestern Amazonia as an early plant domestication and food production centre. PLoS One 13:e0199868. doi: 10.1371/journal.pone.0199868

Webster, B. D., Lynch, S. P., and Tucker, C. L. (1979). A morphological study of the development of reproductive structures of Phaseolus lunatus L. J. Am. Soc. Hortic. Sci. 104, 240-243.

Webster, B. D., Ross, R. M., and Evans, T. (1982). Nectar and the nectary of Phaseolus vulgaris L. J. Am. Soc. Hortic. Sci. 107, 497-503.

Webster, B. D., Ross, R. M., and Sigourney, M. C. (1980). A morphological study of the development of reproductive structures of Phaseolus coccineus Lam. J. Am. Soc. Hortic. Sci. 105, 828-833.

Webster, B. D., Tucker, C. L., and Lynch, S. P. (1977). A morphological study of the development of reproductive structures of Phaseolus vulgaris L. J. Am. Soc. Hortic. Sci. 102, 640-643.

Weinstein, A. I. (1926). Cytological studies on Phaseolus vulgaris. Am. J. Bot. 13, $248-263$.

Wells, S. (2003). The Journey of Man: A Genetic Odyssey. New York, NY: Random House, Inc.

Wells, W. C., Isom, W. H., and Waines, J. G. (1988). Outcrossing rates of six common bean lines. Crop Sci. 28, 177-178.

Wendel, J. F., and Percy, R. G. (1990). Allozyme diversity and introgression in the Galapagos Islands endemic Gossypium darwinii and its relationship to continental G. barbadense. Biochem. Syst. Ecol. 18, 517-528.

Westphal, E. (1974). Pulses in Ethiopia, Their Taxonomy and Agricultural Significance. Ph.D. thesis. (Wageningen: Wageningen University), 140-151.

Wilkes, H. G. (1977). Hybridization of maize and teosinte, in Mexico and Guatemala and the improvement of maize. Econ. Bot. 31, 254-293.

Wortmann, C. S., Kirkby, R. A., Eledu, C. A., and Allen, D. J. (1998). Atlas of Common Bean (Phaseolus vulgaris L.) Production in Africa. Cali: Centro Internacional de Agricultura Tropical.
Wu, J., Wang, L., Fu, J., Chen, J., Wei, S., Zhang, S., et al. (2020). Resequencing of 683 common bean genotypes identifies yield component trait associations across a north-south cline. Nat. Genet. 52, $118-125$.

Xu, R.-Q., Tomooka, N., Vaughan, D. A., and Doi, K. (2000). The Vigna angularis complex: Genetic variation and relationships revealed by RAPD analysis, and their implications for in situ conservation and domestication. Genet. Resour. Crop Evol. 47, 123-134.

Zeven, A. C., Waninge, J., Van Hintum, T., and Singh, S. P. (1999). Phenotypic variation in a core collection of common bean (Phaseolus vulgaris L.) in the Netherlands. Euphytica 109, 93-106.

Zhang, X., Blair, M. W., and Wang, S. (2008). Genetic diversity of Chinese common bean (Phaseolus vulgaris L.) landraces assessed with simple sequence repeat markers. Theor. Appl. Genet. 117, 629-640.

Zizumbo-Villarreal, D., Colunga-Garcíamarín, P., De La Cruz, E. P., Delgado-Valerio, P., and Gepts, P. (2005). Population structure and evolutionary dynamics of wild-weedy-domesticated complexes of common bean in a Mesoamerican region. Crop Sci. 45, 1073-1083.

Zoro Bi, I., Maquet, A., and Baudoin, J.-P. (2003). Population genetic structure of wild Phaseolus lunatus (Fabaceae), with special reference to population sizes. Am. J. Bot. 90, 897-904.

Conflict of Interest: The authors declare that the research was conducted in the absence of any commercial or financial relationships that could be construed as a potential conflict of interest.

Copyright (c) 2021 Chacón-Sánchez, Martínez-Castillo, Duitama and Debouck. This is an open-access article distributed under the terms of the Creative Commons Attribution License (CC BY). The use, distribution or reproduction in other forums is permitted, provided the original author(s) and the copyright owner(s) are credited and that the original publication in this journal is cited, in accordance with accepted academic practice. No use, distribution or reproduction is permitted which does not comply with these terms. 